\title{
Review Article \\ Type I Diabetes Mellitus: Genetic Factors and Presumptive Enteroviral Etiology or Protection
}

\author{
Jana Precechtelova, Maria Borsanyiova, Sona Sarmirova, and Shubhada Bopegamage \\ Enterovirus Laboratory, Faculty of Medicine, Slovak Medical University, Limbova 12, 83303 Bratislava, Slovakia \\ Correspondence should be addressed to Shubhada Bopegamage; shubhada.bopegamage@szu.sk
}

Received 6 May 2014; Revised 14 July 2014; Accepted 9 November 2014; Published 10 December 2014

Academic Editor: Alexander Rodriguez-Palacios

Copyright ( 2014 Jana Precechtelova et al. This is an open access article distributed under the Creative Commons Attribution License, which permits unrestricted use, distribution, and reproduction in any medium, provided the original work is properly cited.

\begin{abstract}
We review type 1 diabetes and host genetic components, as well as epigenetics and viruses associated with type 1 diabetes, with added emphasis on the enteroviruses, which are often associated with triggering the disease. Genus Enterovirus is classified into twelve species of which seven (Enterovirus A, Enterovirus B, Enterovirus C, and Enterovirus D and Rhinovirus A, Rhinovirus $B$, and Rhinovirus $C$ ) are human pathogens. These viruses are transmitted mainly by the fecal-oral route; they may also spread via the nasopharyngeal route. Enterovirus infections are highly prevalent, but these infections are usually subclinical or cause a mild flu-like illness. However, infections caused by enteroviruses can sometimes be serious, with manifestations of meningoencephalitis, paralysis, myocarditis, and in neonates a fulminant sepsis-like syndrome. These viruses are often implicated in chronic (inflammatory) diseases as chronic myocarditis, chronic pancreatitis, and type 1 diabetes. In this review we discuss the currently suggested mechanisms involved in the viral induction of type 1 diabetes. We recapitulate current basic knowledge and definitions.
\end{abstract}

\section{History of Diabetes}

Symptoms of type 1 diabetes (T1D) have been recognized since approximately $1500 \mathrm{BC}$, when they were described on Egyptian papyrus as indicators of a rare disease that caused patients to lose weight rapidly and experience "too great emptying of the urine" $[1,2]$. This was probably the first mention of the disease. At approximately the same time, however, Indian physicians realized that the urine of some patients attracted ants. These doctors classified the disease and named it "madhumeha" or "honey urine" [3]. Later, the disease was called "diabetes" by Greek physician Aretaeus, who noted symptoms such as constant thirst, excessive urination, and loss of weight. "Diabetes" comes from the Greek word for "siphon" (to draw off or convey liquid). The Arabian physician Avicenna (980-1037) was the first to bring attention to the complexity and progression of the disease, recognizing primary and secondary diabetes. In the 17th century, the Latin term "mellitus" meaning "honeyed" or "sweet" was added by Thomas Willis, an English physician, in his treatise Pharmaceutice Rationalis (1674). He tested urine samples of patients to determine the presence of diabetes; those samples with a sweet taste indicated diabetes mellitus or "honeyed" diabetes. In 1776, Matthew Dobson measured the quantity of glucose in the urine samples of diabetic patients. Dr. Frederick Allen, a diabetes specialist in the early 20th century, advised low calorie diets for his diabetic patients. These diets increased the life of his patients, but they often became weak and starved [4].

A critical experiment occurred in 1921 when Frederick Banting and his assistant, Charles Best, kept a dog with diabetes alive for 70 days by injecting it with a turbid mixture of an extract from a canine pancreas. Dr. Collip and Dr. Macleod then helped Banting and Best to administer a more refined extract of insulin to Leonard Thompson, a boy suffering from diabetes. They noted that, within 24 hours, his high blood sugar had dropped to nearly normal levels. Banting and Best received the Nobel Prize in Physiology or Medicine in 1923 for their discovery of insulin. Since that time, scientific interest in this disease and associated glucose metabolism has increased. Ten scientists have received Nobel Prizes for diabetes-related investigations [5]. Sir Harold 
Himsworth reported the existence of two types of diabetes in 1935: "insulin sensitive" (type I) and "insulin insensitive" (type II). His work [6] was an important landmark in the understanding of diabetes and treatment strategies.

\section{Types of Diabetes Mellitus}

Diabetes mellitus (DM) is classified as a group of metabolic diseases with a typical clinical state of hyperglycemia (high blood glucose levels), which is an outcome of defective insulin secretion, insulin action, or both [7]. Hyperglycemia is correlated with typical acute diabetic symptoms that include excessive urine production (polyuria) and high urine sugar levels (glycosuria), the consequences of which are thirst, increased fluid intake (polydipsia), increased eating (polyphagia), weakness, fatigue, blurred vision, unexplained weight loss, and lethargy. Chronic hyperglycemia is further related to prolonged damage, dysfunction, and failure of different organs. Secondary complications due to fluctuations in blood glucose arise from vascular degeneration, which results in damage of eyes, kidneys, nerves, blood vessels, and heart, causing dysfunction and failure of the organs or eventual gangrene with a probable loss of toes, feet, and legs. These complications decrease the quality of life and can eventually lead to premature death. Table 1 shows the recent classification of diabetes according to the American Diabetes Association and World Health Organization which includes four clinical categories of diabetes [7-9]. In this review we focus on type 1 diabetes because it is the most common endocrine disorder in children, with a worldwide increase in incidence.

Type 1 diabetes usually develops before the age of 30, with peaks at 2, 4-6, and 10-14 years of age. Type 1 diabetes patients depend on external insulin (usually injected subcutaneously) for survival. Approximately $5-10 \%$ of diabetics with type 1 diabetes (T1D) show gradual destruction of the insulin producing $\beta$-cells in the pancreas. This destruction leads to absolute insulin deficiency. The disease usually appears when $80-90 \%$ of the $\beta$-cells are destroyed $[10,11]$.

Autoimmune-mediated destruction of $\beta$-cells has been associated with T1D because $85-90 \%$ of the cases show one or more autoantibodies [12]. Some of the autoantigens described by different authors include enzyme glutamic acid decarboxylase (GAD65) [13], insulin (IAA) [14], insulinoma associated antigens (identified as tyrosine phosphatases IA-2 and IA $2 \beta$ ) $[15,16]$, islet cell antigens (ICA69) [17], enzyme carboxypeptidase-H [18], GM-gangliosides [19], $38 \mathrm{kD}$ autoantigen [20], sex determining region-Y box protein (SOX13) [21], and zinc transporter 8 protein (ZnT8A) also known as the solute carrier family 30 member 8 (SLC30A8) [22]. The presence of two or more antibodies has been suggested as predictive markers for T1D [23, 24]. In the present times commercial kits are available and some laboratories have developed in-house methods for detection of some of these antibodies. The predictive value of these markers would be of importance for intervention measures. However, it is difficult to identify the right time to measure these antibodies. Another unclear aspect is whether these antibodies are produced after the cell destruction or if antibodies induce the cellular destruction.

Treatment of T1D usually consists of insulin administration via injections or pumps. Insulin therapy results in improvements, yet $\mathrm{T} 1 \mathrm{D}$ is considered to be a chronic disease for which there is no prevention or cure. The disease progresses in the majority of diabetic patients, and the resulting dysglycemia leads to microangiopathic or neuropathic complications.

\section{Type 1 Diabetes: Major Histocompatibility Complex Related Genetic Factors}

Type 1 diabetes is a multifactorial disorder requiring a genetic predisposition and a trigger for the destructive process as observed in other autoimmune diseases $[25,26]$. T1D has a strong genetic component. Relatives of diabetic patients have a high risk of developing the disease; siblings have a greater risk than offspring, and there is a high concordance rate among identical twins $[27,28]$. This genetic predisposition (or lack thereof) is determined by the balance between susceptibility and resistance alleles. Among various factors the major histocompatibility complex (MHC) glycoproteins are very important in the recognition of the tissues by the immune system.

Genetic wide association studies (GWAS) help to identify and measure the DNA variations in the human genome and identify disease risk factors in a given population. This is done by measuring single nucleotide polymorphism (SNP) changes occurring frequently as single base pair changes in the DNA sequences $[29,30]$. These variations are identified by genotyping using the next-generation sequencing and chip based microarray [31]. Epigenome wide association studies (EWAS), using this modern technology, have shown that, besides the HLA-A, HLA-B, and HLA$\mathrm{DP} \beta 1$, other strong markers include HLA-DR $\beta 1$, HLA$\mathrm{DQ} \alpha 1$, and HLA-DQ $\beta 1$. The HLA-DR $\beta 1^{*}$ 03:01 haplotypes carrying HLA-DR $\beta 3^{*}$ 02:02 alleles showed a higher risk than HLA-DR $\beta 1^{*}$ 03:01 haplotypes carrying $\mathrm{DR} \beta 3^{*} 01: 01$ in $\mathrm{DR} \beta 1^{*}$ 03:01/*03:01 homozygotes with two $\mathrm{DR} \beta 3^{*}$ 01:01 alleles [31-35].

The human leukocyte antigen (HLA) region of the $6 \mathrm{p} 21$ chromosome encodes glycoprotein of the MHC, which has a function in presenting antigenic peptides to T-cells. MHC is a cluster of genes that are situated on the short arm of chromosome 6 and vary in length, depending on their haplotypes. The MHC locus first discovered by Snell and Higgins [36] comprises 121 functional genes, which include all of the MHC class I and MHC class II genes. MHC I molecules constitutively expressed in most cells present antigens for binding to CD8+ T-cells and display peptides from proteins synthesized within the cell. On the other hand MHC II molecules constitutively expressed in antigenpresenting cells (APCs), such as macrophages, dendritic cells, and B-cells, are important to the human immune response because they present peptide antigens to T-helper (CD4+) cells, revealing peptides from engulfed proteins present in thymic stromal cells or antigen-presenting cells [37-39]. 
TABLE 1: Current and former classifications of diabetes mellitus.

\begin{tabular}{lll}
\hline $\begin{array}{l}\text { Former classification } \\
\text { (based on treatment) }\end{array}$ & Current classification & Cause $^{*}$ \\
\hline $\begin{array}{l}\text { Insulin-dependent diabetes } \\
\text { mellitus (IDDM) }\end{array}$ & Type 1 diabetes (T1D) & $\beta$-cell destruction that leads to total insulin deficiency \\
\hline $\begin{array}{l}\text { Non-insulin-dependent diabetes } \\
\text { mellitus (NIDDM) }\end{array}$ & Type 2 diabetes (T2D) & $\begin{array}{l}\text { A progressive defect in insulin secretion in combination } \\
\text { with insulin resistance }\end{array}$ \\
\hline & $\begin{array}{l}\text { Other types of diabetes: maturity-onset } \\
\text { diabetes of the young (MODY), neonatal } \\
\text { diabetes mellitus (NDM), genetic } \\
\text { syndrome associated with diabetes }\end{array}$ & $\begin{array}{l}\text { Genefin in function of the } \beta \text {-cells. Other factors } \\
\text { include pathophysiology of the pancreas (cystic fibrosis } \\
\text { in patients. }\end{array}$ \\
$\begin{array}{ll}\text { Heterogenic } \\
\text { Syndromes: Down syndrome, Huntington's chorea, } \\
\text { Prader-Willi syndrome, diabetes insipidus, } \\
\text { Rabson-Mendenhall syndrome, and immune-mediated } \\
\text { disorders such as systemic lupus erythematosus }\end{array}$ \\
\hline Heterogenic & $\begin{array}{l}\text { Gestational diabetes (GD) diagnosed } \\
\text { during pregnancy }\end{array}$ & $\begin{array}{l}\text { Related to hormonal changes, low insulin levels, } \\
\text { nutritional and genetic factors }\end{array}$ \\
\hline
\end{tabular}

${ }^{*}$ Causes or current definitions as per [7-9].

MHC II molecules are also inducible in some tissues by cytokines such as interferon gamma (IFN- $\gamma$ ) [40].

In humans MHC I molecules comprise the HLA-A, HLA$\mathrm{B}$, and HLA-C while MHC II molecules include HLA-DP, $\mathrm{DQ}$, and DR, which have the strongest association with T1D as summarized in Figure 1 and Table 2. Two types of MHC II genes encode alpha polypeptides and beta polypeptides and together form the functional class II alpha-beta heterodimer. They form major $\mathrm{DP} \alpha, \mathrm{DP} \beta, \mathrm{DQ} \alpha, \mathrm{DQ} \beta, \mathrm{DR} \alpha$, and $\mathrm{DR} \beta$, plus minor DM and DO genes that encode MHC II proteins on the APCs. Both the alpha and beta polypeptide genes are polymorphic [37-43]. These proteins are important because of their role in triggering of autoimmune and inflammatory responses.

Autoimmune diseases such as systemic lupus erythematosus and psoriasis have been linked to MHC III and MHC IV loci $[43,44]$ but so far association of these loci with the T1D has not been investigated and remains a novel area for research. MHC III region is highly conserved but is more heterogeneous than MHC I and MHC II regions. The MHC III genes are located between the MHC I and MHC II on the short arm of chromosome 6 [43]. Figure 1 and Table 2 summarize the location of these loci. The human MHC III region contains 61 genes which encode the MHC class III molecules. These are proteins which are components of the immune and complement system such as C2, C4, and B factor. Lastly, MHC IV genes are involved in the production of several factors: tumor necrosis factor alpha (TNF- $\alpha$ ), lymphotoxin alpha (LTA) and lymphotoxin beta (LTB), B144/LST protein expressed in dendritic cells and involved in their morphogenesis, $1 \mathrm{C} 7$ expressed in the natural killer (NK) cells and responsible for their activation, the G1 and allograft inflammatory factor 1 (AIF1) which are inflammatory markers, superkiller 12W (SK12W) that confers antiviral activity, B associated transcript (BAT1) encoding a protein with helicase motifs, heat shock proteins (HSP) related to proinflammatory cytokines and protection against cellular inflammation/apoptosis, and MIC A and MIC B genes coding for the MIC A and MIC B proteins which play a role in activation of natural killer cells [44]. The MHC III and MHC IV genes are involved in the antigen processing (but not presenting) and production of proinflammatory cytokines.

The influence of a particular HLA molecule on susceptibility to any disease depends on its three-dimensional structure $[45,51,52]$. The diabetogenic and protective molecules differ in structure. The differences result in varied antigen peptide selectivity, binding affinity, and the stability of the HLA molecule presented on the cell surface. The HLA molecules react with distinct peptide binding motifs and interact differently with a given diabetogenic autoantigen. The disease susceptibility conferred by HLA represents the combined effect of several genes within the MHC. At least three major loci are involved (HLA-DR $\beta 1$, HLA-DQ $\alpha 1$, and HLA-DQ $\beta 1$ ), but several other genes may also contribute $[46,53]$.

Susceptibility to T1D is most strongly determined by $\mathrm{DQ} \beta 1$ and $\mathrm{I}-\mathrm{A} \beta$ equivalent chain allele for $\mathrm{MHC}$ in mice that encode serine, alanine, or valine at position 57 on both chromosomes. In contrast $\mathrm{DQ} \beta$ and I-A $\beta$ in mice at position 57 aspartic acid positive alleles mediate resistance to T1D. To some extent, resistance is also mediated by DR $\beta 1$ and I-E $\beta$ in mice expressing aspartic acid at position 57 or glutamine at position 74 [47]. It has been suggested that HLADQ and HLA-DR polymorphism affects the susceptibility to T1D through the selectively affecting nature of the peptides presented to T-cells [48]. One copy (allele) of the DR3 or DR4 is found commonly in the general population. Individuals, susceptible to T1D, inherit two alleles DR3/DR3, DR4/DR4 or the high risk DR3/DR4 combination $[49,50]$ (Table 2). Heterogeneity in these alleles may increase or decrease the disease risk.

\section{Epigenetics}

Epigenetics is a study of heritable changes which are not a consequence of mutations in the DNA but occur as alterations 


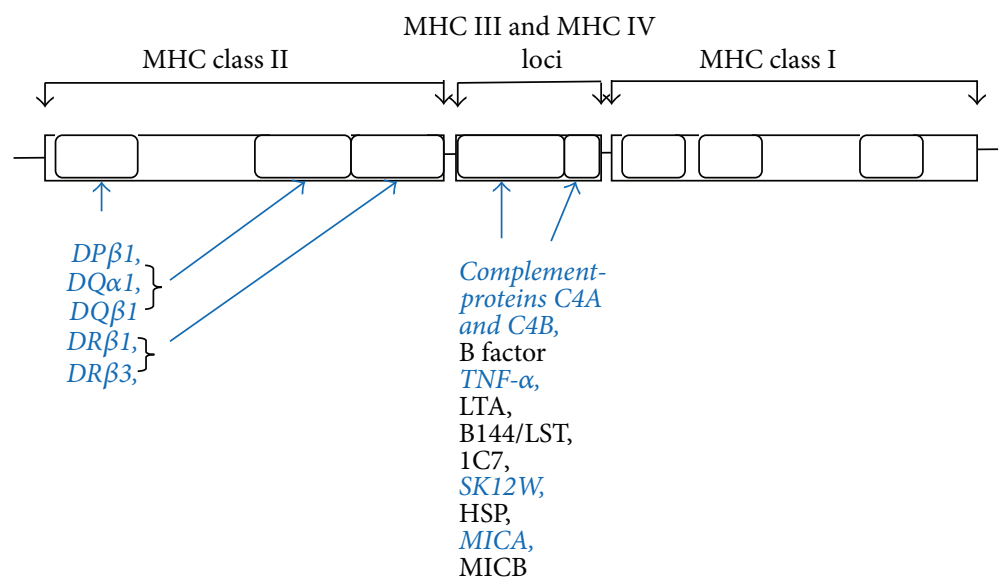

FIGURE 1: Major histocompatibility complex loci associated with type 1 diabetes. The known loci and products participating in the triggering of type 1 diabetes are marked in blue and italics.

TABLE 2: The major histocompatibility complex and the human leukocyte antigens**

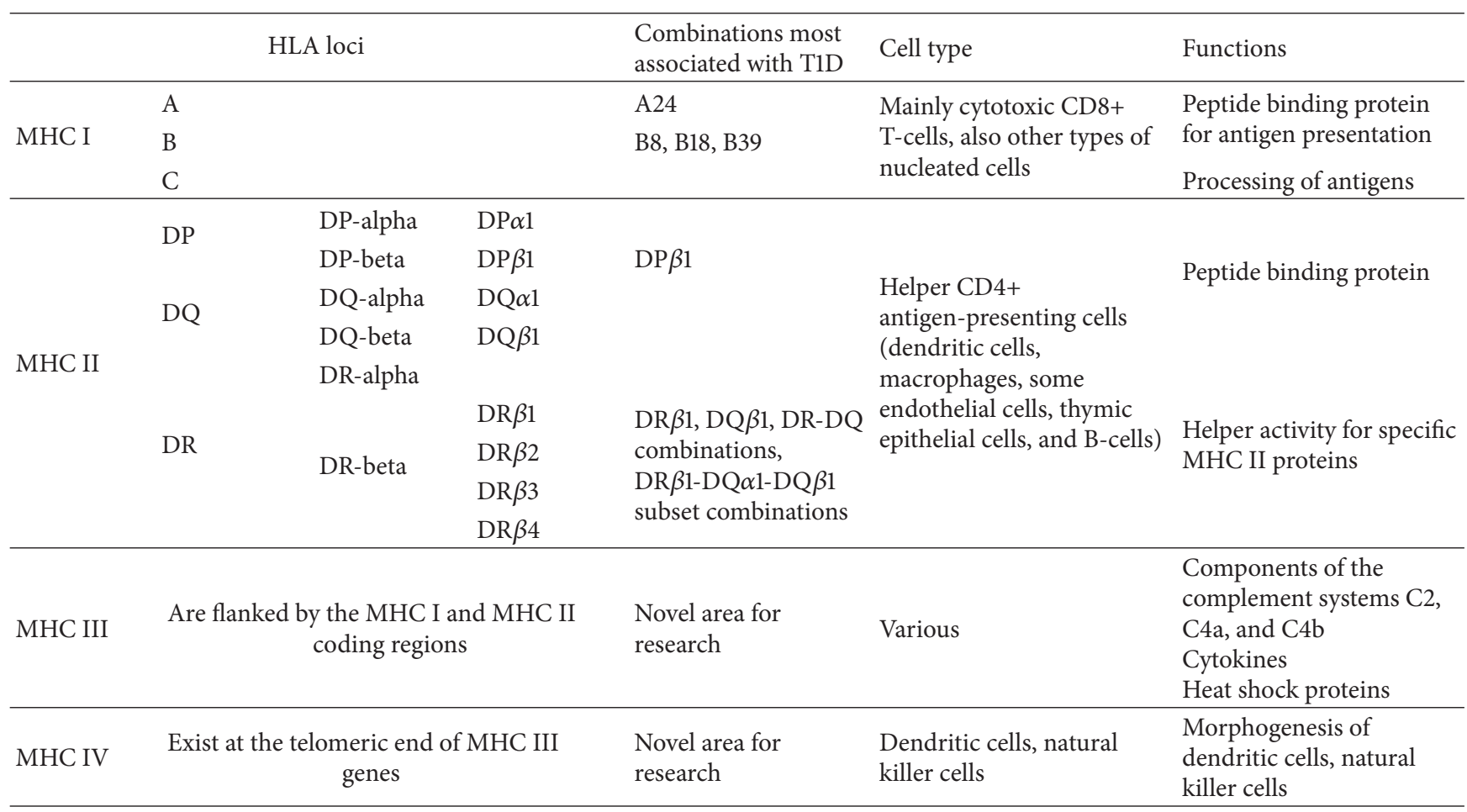

${ }^{*}$ References [9, 29-36, 41-50].

at the transcriptional level. Increasing knowledge of the immune mechanisms that have the largest impact on the disease, modern molecular technology, and recent developments in the understanding of meta-analysis and epigenetics show that the T1D risk is a combination of reactions or a dialogue among four major factors: (1) primary T1D-related genetic susceptibility genes; (2) triggering immunological factors that may vary and act as stimuli; (3) other factors such as epigenetic heterogeneity caused by environmental factors; and (4) interactions with genes related to other (immunological and apoptotic) pathways expressed locally in pancreatic $\beta$-cells. Each of these factors has been reviewed elsewhere in recent years [35].
In addition to inherited alleles, other mechanisms regulating gene expression include "parent-of-origin effects" (marker from either the maternal or paternal allele), which can modify the inheritance and/or transcription of susceptibility genes [54]. The "parent-of-origin effects" show the differential behavior of the genes depending on the parent from whom they were inherited and relating them to different diseases [55]. The influence of the susceptibility to T1D in the offspring is stronger and more frequent to the father than the mother ranging from 6 to 9\% [56-58]. The "parent-oforigin" susceptibility transmission also varies for different antibodies, with greater prevalence in children from diabetic fathers than mothers [59]. Alteration of DLK1-MEG3 gene 
region on chromosome $14 \mathrm{q} 32.2$ in the father appears to influence the susceptibility to T1D [60].

GWAS identified epigenetic modifications, which are changes in gene expression, and gene function without changes in the gene sequence. The three mechanisms defined include (1) the methylation of cytosine residues in DNA at position 5 (moving clockwise from $\mathrm{NH}_{2}$, which is counted as position 0 ) of the 6 -atom ring of cytosine, associated with transcriptional repression or posttranslational modification; (2) N-terminal histones that may be affected by posttranslational modifications through acetylation, methylation, or phosphorylation; and (3) demethylation of miRNA. Rakyan et al. [61] analyzed DNA methylation variable positions (MVPs) for T1D on monocytes of monozygotic twins discordant for T1D. The MVPs were sought in these monozygotic twins in order to rule out typical genetic factors. The authors [61] showed that the methylations were not an effect of the disease but occurred prior to the disease.

\section{Non-MHC Complex Genes Related to T1D}

Since the first association of MHC and T1D [26, 62], a number of other non-MHC-related genes and immune mediators have been associated with T1D. Such genes include the insulin gene, cytotoxic T-lymphocyte antigen 4 gene (CTLA4) [26, $63,64]$, protein tyrosine phosphatase N22 gene (PTPN22) [65], IL-2 receptor alpha (IL-2RA) [66], and interferon induced with helicase C domain 1 (IFIH1) gene [29]. GWAS studies and the non-MHC genes related to T1D have been discussed and compared by Bakay et al. [67].

Nejentsev et al. [68] identified four variations in the interferon induced with helicase $\mathrm{C}$ domain 1 (IFIH1) gene, which might be associated with reduced risk of developing T1D. The helicase enzyme IFIH1 (also known as MDA5 or melanoma differentiation-associated protein-5) triggers the secretion of interferons in response to viral infection. The interferon-regulating factor 7- (IRF7-) driven inflammatory network (IDIN) genes also contribute to the risk of T1D [69].

Different non-MHC candidate gene products related to T1D involving the cytokine pathways are IL-12B, 2' $5^{\prime}$-oligoadenylate synthetase 1 (OAS1), small ubiquitin-like modifier 4 (SUM04), paired box gene 4 (PAX4), protein tyrosine phosphatase N2 gene (PTPN2), regulatory and proinflammatory T-cells, macrophage-related cytokines including interferon gamma (IFN- $\gamma)$, tumor necrosis factor alpha (TNF- $\alpha$ ), interleukin- 4 and interleukin-10 (IL-4 and IL-10), and C-type lectin domain family 16 (CLEC16A) [29, 6981]. Table 3 shows the overview of the non-MHC genes and gene products associated with T1D and the chromosomes on which they are located. Although the functions of each of these products are well known in the regulation of the immune system (Table 3 ) their exact role inducing T1D remains unclear.

The multigenic nature of $\mathrm{T} 1 \mathrm{D}$ has been recognized through meta-analysis studies $[73,82]$ and genetic epidemiology $[83,84]$. To date several MHC and immune-related genes associated with antigen presentation and inflammatory regulation appear to serve as risk factors for T1D.

\section{Genetic Mechanisms for T1D Predisposition or Protection}

The interaction between cellular, immune, and genetic factors determines if a particular (experimental) system is prone to protection or predisposition to T1D. Studies on the involvement of B-cells in the induction of diabetes are limited. B-cells are common in inflamed insulin producing pancreatic islets [85-87]. Single nucleotide polymorphism analysis indicates the following variants are associated with T1D and B-cell receptor (BCR) and B-cell differentiation: PTPN22, PTPN2, Src homology 2B3 adapter gene (SH2B3), and immunoregulatory cytokines IL-10, IL-19, and IL-20 [88, 89]. Peripheral B-cell proliferation was shown to be related to the cytokine IL-10, and the "IL2-IL21 T1D" locus was associated with IL-10 production by the memory B-cells and the autoreactive T-cells [89]. B-cell subsets that might be linked to autoimmune diseases and related views have been discussed by Yang et al. [90]. The regulatory B-cells (Breg) influence the responses of regulatory T-cells, effector cells, and invariant natural killer T-cells (iNKT) and activate the dendritic cells through cytokines. These cytokines are mainly the IL-10 and tumor growth factors (TGF), together influencing T1D. Research related to B-cell subtypes and T1D is increasingly accumulating.

Normally islet $\beta$-cells express low levels of IFNs, but viral infections may result in high levels of IFN production, which further increase MHC I expression leading to high susceptibility to cytotoxic CD8+ T-cell recognition and destruction [91]. Therefore, normal IFIH1 gene-mediated immune responses activated by some viruses may stimulate autoimmunity against pancreatic $\beta$-cells. However, mutations in IFIH1 gene disrupt this mechanism inducing protection against T1D by production of protein product MDA5 with an impaired function $[68,92]$.

Interferons can be identified as type I (IFN- $\alpha$ and IFN- $\beta$ ), type II (IFN- $\gamma$ ), and type III (IFN- $\lambda$ ). Among type 1 interferons the best studied ones are interferons alpha (IFN- $\alpha$ ) and beta (IFN- $\beta$ ). These interferons are induced via stimulation of different transmembrane and cytosolic receptors. The main receptors responsible for type I interferon induction in response to infections and double stranded RNAs (dsRNAs) are the RNA helicases retinoic acid inducible gene 1 (RIG1) and melanoma differentiation-associated gene 5 (MDA5). Type 1 interferons are produced by most cell types, including plasmacytoid dendritic cells [93]. IFN- $\alpha$ usually limits viral replication, but, on the other hand, together with inflammatory cytokines IL- $1 \beta$ and TNF- $\alpha$, these interleukins can cause direct cellular damage [94]. $\beta$-cells of the pancreatic islets express IFN- $\alpha$ [95]. Sera of T1D patients have increased titers of IFN- $\alpha$ [96]. Of epidemiological relevance IFN $-\alpha$ in the plasma of patients with detectable enteroviral-RNA [97] has been found to be in high concentrations.

Type II interferons (IFN- $\gamma$ ) are produced by different cells types. They enhance the MHC class I and class II expression via the protein tyrosine kinase of the Janus family (Jak 1 and Jak 2) leading to phosphorylation of the tyrosine in STAT1 $[98,99]$. Interferon gamma (IFN- $\gamma)$ interacts with IFN- $\alpha$. In autoimmune diseases, type I interferons induced by the 
TABLE 3: Nonmajor histocompatibility complex genes and gene products associated with type 1 diabetes by genome wide association studies.

\begin{tabular}{|c|c|c|}
\hline $\begin{array}{l}\text { Chromosome* } \\
\text { number }\end{array}$ & Gene $^{*}$ & Function of the gene product \\
\hline Chromosome 1 & $\begin{array}{l}\text { Protein tyrosine phosphatase nonreceptor } 22 \text { gene } \\
\text { (PTPN22) }\end{array}$ & Plays a role in T-cell receptor signaling \\
\hline Chromosome 1 & Interleukin-10 (IL-10) & $\begin{array}{l}\text { Downregulates expression of MHC II antigens } \\
\text { and Th1 cytokines and is involved in cell } \\
\text { mediated and cytotoxic inflammatory response }\end{array}$ \\
\hline Chromosome 2 & $\begin{array}{l}\text { Including cytotoxic T-lymphocyte antigen } 4 \\
\text { (CTLA4) }\end{array}$ & $\begin{array}{l}\text { Expressed by CD } 4+\text { and CD } 8+\text { T-cells and } \\
\text { downregulates T-cell proliferation and } \\
\text { cytokine production }\end{array}$ \\
\hline Chromosome 2 & $\begin{array}{l}\text { Interferon induced with helicase C domain } 1 \\
\text { (IFIH1/MDA-5) }\end{array}$ & $\begin{array}{l}\text { Triggers the secretion of interferons in } \\
\text { response to viral infections }\end{array}$ \\
\hline Chromosome 5 & Interleukin-4 (IL-4) & $\begin{array}{l}\text { Induces differentiation of naive T-cells to } \\
\text { T-helper cells but suppresses interferon- } \gamma \text { and } \\
\text { IL-2 producing Thl cells }\end{array}$ \\
\hline Chromosome 5 & $\begin{array}{l}\text { Interleukin-12 beta also known as interleukin-12p } 40 \\
\text { (IL-12B) }\end{array}$ & $\begin{array}{l}\text { Produced by antigen-presenting cells and } \\
\text { drives the differentiation of CD } 4+\text { T-cells into } \\
\text { Th1 cells }\end{array}$ \\
\hline Chromosome 6 & Small ubiquitin-like modifier 4 (SUM04) & $\begin{array}{l}\text { Polymorphism in this gene leads to activation } \\
\text { of nuclear factor kappa B }\end{array}$ \\
\hline Chromosome 6 & Tumor necrosis factor alpha (TNF- $\alpha$ ) & $\begin{array}{l}\text { Stimulates inflammatory reactions and } \\
\text { phagocytosis }\end{array}$ \\
\hline Chromosome 7 & Paired box gene 4 (PAX4) & $\begin{array}{l}\text { Plays a role in tissue development and is found } \\
\text { on pancreatic islet cells }\end{array}$ \\
\hline Chromosome 10 & IL-2 receptor-alpha (IL-2RA) & $\begin{array}{l}\text { Its expression on T-cells is necessary for } \\
\text { suppressing T-cell response }\end{array}$ \\
\hline Chromosome 11 & Insulin (INS) & Controls glucose levels in the blood \\
\hline Chromosome 12 & $2^{\prime}-5^{\prime}$-Oligoadenylate synthetase 1 (OAS1) & $\begin{array}{l}\text { Enzyme involved in the innate immune } \\
\text { response induced by interferons against viral } \\
\text { infections }\end{array}$ \\
\hline Chromosome 12 & Interferon gamma (IFN- $\gamma)$ & $\begin{array}{l}\text { Cytokine involved in the inflammatory } \\
\text { responses, produced by different natural killer } \\
\text { cells, CD } 4+\text {, and CD } 8+\text { T-cells }\end{array}$ \\
\hline Chromosome 13 & $\begin{array}{l}\text { Interferon-regulating factor 7- (IRF7-) driven } \\
\text { inflammatory network (IDIN) }\end{array}$ & $\begin{array}{l}\text { Present in monocytes and regulated by viral } \\
\text { responses }\end{array}$ \\
\hline Chromosome 16 & C-type lectin domain family 16 (CLEC16A) & $\begin{array}{l}\text { Expressed in most of the immune cells and } \\
\text { plays a role in the antigen uptake }\end{array}$ \\
\hline Chromosome 18 & $\begin{array}{l}\text { Tyrosine protein phosphate nonreceptor } 2 \text { gene } \\
\text { (PTPN2) }\end{array}$ & Regulates proinflammatory cytokines \\
\hline
\end{tabular}

${ }^{*}$ References [25-27, 29, 63-81].

plasmacytoid dendritic cells may upregulate or downregulate the IFN- $\gamma$ which in turn affects the MHC expression and apoptosis [100]. Whereas type III interferons, also known as interferon lambda (IFN- $\lambda$ ), are restricted only to few cell types, they may affect the viral replication and reduce viral induced damage to tissues. This was observed in primary human pancreatic islet cells recently [101] leading to their protection from coxsackievirus infection. The IFN- $\lambda$ and its association with T1D could be a new area for investigation.

The relevance of genetic factors modulating the expression and function of various types of interferons and other immune-related cytokines is related to their critical importance in controlling infections. Among the various possible infections agents, viruses have been the most studied and consistently associated with the mechanisms and predisposition to T1D. A growing body of literature on in vitro and in vivo experiments indicates that viruses may drive unspecific inflammatory or immune responses against pancreatic cells critical in blood glucose homeostasis.

\section{Viruses and Predisposition to Type 1 Diabetes}

Viruses, with their potential to induce innate and adaptive immune responses and local inflammation in target organs, are suspected of initiating autoimmune processes. The etiologic link between T1D and viruses is based on 
epidemiological, serological, and histological findings, as well as experimental in vivo and in vitro studies. These include the DNA viruses from families Herpesviridae and Parvoviridae and RNA viruses of families Togaviridae, Paramyxoviridae, Retroviridae, and Picornaviridae (Tables 4 and 5). The viral genetics, host genetics, host immunological status, age at the time of exposure to the virus, and the pancreatic microenvironment may influence triggering of T1D related to $\beta$-cell damage. A systematic review and meta-analysis of observational molecular studies in 2011 showed a strong association between T1D and enteroviruses [82]. Tables 4 and 5 show the different viruses and the mechanisms of induction of T1D. Also the proposed mechanisms related to the virusinduced impact on the pancreatic beta cells have been studied using animal/in vitro models and enteroviruses.

7.1. Human Cytomegalovirus. In 1979, the human cytomegalovirus (HCMV), also known as human herpes virus-5 (HHV-5), was first linked to T1D [124] onset following a congenital infection by this virus. These findings were confirmed by detection of cytomegalovirus genome in $22 \%$ of diabetic patients correlating with the presence of islet cell antibodies (ICA) [102]. The same group showed cross-reactivity of anticytomegalovirus antibodies with $38 \mathrm{kD}$ human pancreatic islet-specific protein [125]. The virus infected human fetal islets in vitro, yet direct destruction of $\beta$-cells was absent [126]. The different mechanisms suggested for the role of human cytomegalovirus in diabetogenesis maybe related to (1) molecular mimicry induced by T-cell cross-reactivity between human cytomegalovirus and GAD65 (glutamic acid decarboxylase exists as two isoforms GAD65 and GAD67, a major enzyme required for the production of the gamma amino butyric acid which regulates the glucagon secretion) in pancreatic islet $\beta$-cells $[102,103]$; (2) the persistence of HCMV specific CD4+ T-cells or a bystander activity [104]; and (3) persistent infection in $\beta$-cells [127]. However, other groups $[128,129]$ failed to find a link between the virus and T1D; no human cytomegalovirus DNA was found in the formalin-fixed pancreases of patients with T1D [130,131]. The contribution of human cytomegalovirus to the diabetogenic process is not clear yet and controversial; more clinical and model studies related to this virus and T1D are required.

7.2. Parvovirus. Parvovirus B19 belongs to family Parvoviridae, genus Erythroparvovirus. The virus may affect individuals of any age, but the infections are common in children aged six to ten. Typical syndromes are headache, nausea, diarrhea and fever with red rash, and chronic anemia in HIV patients. Elevated serum anti-parvovirus B19 IgM and antibodies to the autoantigen IA-2 have been described with a homology in amino acid sequences between B19 and the extracellular domain of IA-2 [105]. The autoantigen IA-2 (islet cell antigen 512 ) is a member of the protein tyrosine phosphatase, secreted by the pancreatic endocrine cells and a regulator of insulin synthesis. A link between acute parvovirus B19 infection and T1D has been shown [132]. Parvovirus B19 can stimulate Tcell-mediated proliferative response. It activates autoimmunity by presentation of HLA class II antigen to CD4+ T-cells
$[106,133]$. Studies on the Kilham rat virus (KRV) belonging to the same genus have suggested molecular mimicry [134] and initiation of innate immunity in the pancreatic lymph nodes [135]. In vivo, in vitro, and epidemiological evidence are required to define further the role of these viruses in T1D induction.

7.3. Rotavirus. Species Rotavirus $A$ is the most common cause of childhood gastroenteritis and is suspected of triggering T1D. Association between rotavirus and T1D was shown by Honeyman et al. [136], who demonstrated specific seroconversion and increase in autoantibodies in T1D patients. In the experimental model, rotavirus infection caused inflammation of the insulin producing cells and induction of diabetes, which was attributed to $\beta$-cell autoimmunity [137]. The authors suggested a possible mechanism which involves increased exposure of $\beta$-cells to immune recognition and activation of autoreactive T-cells by proinflammatory cytokines. Rotavirus could induce or affect the islet autoimmunity by molecular mimicry because rotavirus contains peptide sequences, in VP7 (viral protein 7), highly similar to T-cell epitopes in the islet autoantigens glutamic acid decarboxylase-65 and tyrosine phosphatase IA-2 [107]. The published literature is insufficient to make any conclusive remarks with respect to the inductive role which rotaviruses have on T1D [138].

7.4. Rubella Virus. Infection by rubella virus during pregnancy has been related to increased risk of diabetes in the offspring suffering from congenital rubella syndrome. Congenital rubella was associated with induction of islet autoantibodies in $10 \%$ to $20 \%$ of congenital rubella cases with patients 5 to 25 years of age $[108,139]$. Children who have rubella antibodies present before measles-mumps-rubella vaccination have been shown to have higher levels of islet cell autoantibodies than do seronegative children [140, 141]. Molecular mimicry has been suggested as the mechanism for the association of rubella virus with T1D induction, where the cross-reaction between glutamic acid decarboxylase and various rubella peptides by T-cells is involved [109]. Experimental in vitro studies and in vivo hamster models suggest direct $\beta$-cell infection and cytolysis. Rubella may fit the classical picture of viruses involved in the triggering of T1D. However, the reduced rubella infections after the introduction of the measles-mumps-rubella vaccination and the increase in T1D cases (an inverse relationship) in the world seem to be contradictory. The measles-mumps-rubella vaccination and autoantibody induction hypotheses are more likely to be related to T1D than are direct infection and cytolysis. More factors likely play a role in the onset, but more studies are required in this regard.

7.5. Mumps Virus. Mumps virus has demonstrated the ability to infect $\beta$-cells, leading to a decrease in insulin secretion in the human fetal cultured islet. The infection is associated with an increase of the HLA class I molecule expression, which could influence the autoimmune process in prediabetic individuals by increasing the activity of autoreactive cytotoxic 
TABLE 4: An overview of the viruses associated with T1D and their classification.

\begin{tabular}{|c|c|c|c|c|}
\hline Viruses & Species & Genus & Family & Genome \\
\hline Human cytomegalovirus & Human cytomegalovirus & Cytomegalovirus & Herpesviridae & dsDNA \\
\hline Parvovirus B19 & Primate erythroparvovirus 1 & Erythroparvovirus & Parvoviridae & ssDNA \\
\hline Kilham rat virus & Rodent protoparvovirus 1 & Protoparvovirus & Parvoviridae & ssDNA \\
\hline Rotavirus & Rotavirus A & Rotavirus & Reoviridae & dsRNA \\
\hline Rubella virus & Rubella virus & Rubivirus & Togaviridae & Positive ssRNA \\
\hline Mumps virus & Mumps virus & Rubulavirus & Paramyxoviridae & Negative ssRNA \\
\hline Human endogenous retrovirus & & & Retroviridae & ssRNA \\
\hline Encephalomyocarditis virus- $\mathrm{K}$ & Encephalomyocarditis virus & Cardiovirus & Picornaviridae & Positive ssRNA \\
\hline Parechovirus & Human parechovirus & Parechovirus & Picornaviridae & Positive ssRNA \\
\hline Echovirus & Enterovirus B & Enterovirus & Picornaviridae & Positive ssRNA \\
\hline Coxsackievirus & Enterovirus $B$ & Enterovirus & Picornaviridae & Positive ssRNA \\
\hline
\end{tabular}

TABLE 5: Viruses linked with type 1 diabetes in humans.

\begin{tabular}{|c|c|c|c|}
\hline Virus & Family & Mechanism of the T1D induction & Model system \\
\hline \multirow{3}{*}{$\begin{array}{l}\text { Human } \\
\text { cytomegalovirus }\end{array}$} & \multirow{3}{*}{ Herpesviridae } & Persistent infection [102] & Lymphocytes and autoantibodies (clinical study) \\
\hline & & Molecular mimicry [103] & $\begin{array}{l}\text { GAD65-specific T-cells cross-react with a peptide of } \\
\text { the HCMV (in vitro) }\end{array}$ \\
\hline & & Bystander activation [104] & $\begin{array}{l}\text { Activation of CD4+ and CD8+ T-cells (clinical } \\
\text { study) }\end{array}$ \\
\hline \multirow[t]{2}{*}{ Parvovirus } & \multirow[t]{2}{*}{ Parvoviridae } & Molecular mimicry [105] & $\begin{array}{l}\text { Elevated serum anti-parvovirus B19 IgM and } \\
\text { autoantibodies (clinical study) }\end{array}$ \\
\hline & & Induction of autoimmunity [106] & Prolonged autoimmune alterations (clinical study) \\
\hline Rotavirus & Reoviridae & Molecular mimicry [107] & $\begin{array}{l}\text { Correlation in the proliferative responses of T-cells } \\
\text { to the similar peptides in rotavirus and islet } \\
\text { autoantigens (in vitro) }\end{array}$ \\
\hline \multirow[t]{2}{*}{ Rubella virus } & \multirow[t]{2}{*}{ Togaviridae } & Congenital infection [108] & $\begin{array}{l}\text { Children with congenital rubella-autoantibodies } \\
\text { (clinical study) }\end{array}$ \\
\hline & & Molecular mimicry [109] & $\begin{array}{l}\text { T-cell response to viral and beta cell peptides (in } \\
\text { vitro) }\end{array}$ \\
\hline \multirow{2}{*}{ Mumps virus } & \multirow[b]{2}{*}{ Paramyxoviridae } & Loss of tolerance toward $\beta$-cells [110] & $\begin{array}{l}\text { Human insulinoma cell line infected with mumps (in } \\
\text { vitro) }\end{array}$ \\
\hline & & Molecular mimicry $[111]$ & $\begin{array}{l}\text { Antibodies in serum of vaccinated and } \\
\text { nonvaccinated children (clinical study) }\end{array}$ \\
\hline $\begin{array}{l}\text { Human } \\
\text { endogenous } \\
\text { retrovirus }\end{array}$ & Retroviridae & Influence of the immune response [112] & $\begin{array}{l}\text { Presence of antigen in T-cell subsets of patients } \\
\text { (clinical study) }\end{array}$ \\
\hline $\begin{array}{l}\text { Human } \\
\text { parechovirus }\end{array}$ & Picornaviridae & Induction of autoimmunity [113] & Stool samples and autoantibodies (clinical study) \\
\hline Echovirus & Picornaviridae & Molecular mimicry [114] & $\begin{array}{l}\text { Echovirus } 9 \text { isolated from baby was destructive for } \\
\text { human islets (in vitro) }\end{array}$ \\
\hline \multirow{9}{*}{ Coxsackievirus } & \multirow{9}{*}{ Picornaviridae } & Direct cellular injury [115] & CVB4 and SJL/J mice (in vivo) \\
\hline & & Delayed viral clearance [116] & Serum of prediabetic children (clinical study) \\
\hline & & Molecular mimicry [117] & $\begin{array}{l}\text { Autoantibodies in human blood samples (clinical } \\
\text { study) }\end{array}$ \\
\hline & & Bystander activation [118] & CVB4 and NOD and BDC2.5 mice (in vivo) \\
\hline & & $\begin{array}{l}\text { Antibody-dependent enhancement } \\
\text { [119] }\end{array}$ & $\begin{array}{l}\text { CVB4 and human serum-PBMC and monocyte (in } \\
\text { vitro) }\end{array}$ \\
\hline & & Phagocytosis of infected $\beta$-cells [120] & $\begin{array}{l}\text { CVB3-infected human and porcine pancreatic islets } \\
\text { (in vitro) }\end{array}$ \\
\hline & & Loss of regulatory T-cells [121] & $\begin{array}{l}\text { CVB4-E2 infection of human thymic epithelial cells } \\
\text { (in vitro) }\end{array}$ \\
\hline & & Increased intestine permeability [122] & Virus presence in the small intestine biopsy samples \\
\hline & & Disruption in $\beta$-cells neogenesis [123] & CVB4-E2 or CVB4-JVB and SJL/J mice \\
\hline
\end{tabular}


T-cells [142]. Cavallo et al. [110] showed that the mumps virus infection was related to IL-1 and IL-6 release, so mumps could induce diabetes by decreasing tolerance toward $\beta$ cells and making them more sensitive to immune-mediated destruction.

A high number of children with mumps showed islet cell antigens for 2-15 months following the infection with this virus [143]. Another study associated the virus with an increase in the incidence of T1D [144]. A shared epitope, 7amino-acid-long in the mumps virus nucleocapsid and in MHC class II molecule, has been suggested as the cause of immunological cross-reactivity between these molecules [111]. Regarding the rubella virus and measles-mumpsrubella vaccination, a similar suggestion has been made: mumps infections have decreased, while TD1 incidence has increased [144]. More investigations are required to shed light on the mumps virus studies.

7.6. Human Endogenous Retroviruses. Endogenous retroviruses (ERVs) represent the proviral phase of exogenous retroviruses that have integrated into the host cells. In humans, the most active endogenous retroviruses are members of Human endogenous retroviruses which are not included in the classification of the family Retroviridae [145], forming a part of the human genome. Retroviruses can integrate with the human genome so their genes are either inherited (derived from old viral infections of the germ cells) or acquired after birth. Environmental factors (diet, common viral infections, and/or the sex-hormone changes) may activate endogenous retrovirus genes which then work as a triggering factor [112]. Human endogenous retrovirus genes could be transcribed, expressed in protein, and responsible for the development of autoantibodies that might react against host proteins and these mechanisms could lead to T1D. Human endogenous retrovirus- $\mathrm{K}$ may influence the immune response through insertion close to or in neighboring genes involved in immune epigenetic regulation. Human endogenous retroviruses are known to induce proinflammatory cytokines production, as IL-1 $\beta$, IL6 , or TNF- $\alpha$, through cells, such as monocytes [146]. This virus may involve a combination of the epigenetic factor with other components in the triggering of T1D.

\section{Special Viral Family: Picornaviridae}

Of the viral agents involved in presumptive triggering of T1D, the most studied ones belong to the family Picornaviridae. We will first describe the viruses that are linked to the induction of T1D in experimental animals (natural nonhuman hosts) but have the potential to infect humans in rare conditions. Then, we will describe the viruses that are shown to be associated with T1D in human clinical cases. Figure 2 shows a schematic representation of the different viruses of this family and the suggested mechanisms for the destruction of pancreatic islets and function.

8.1. Encephalomyocarditis Virus. Encephalomyocarditis virus belongs to the genus Cardiovirus of the Picornaviridae family.
The common hosts of these viruses are rodents and pigs although the virus can infect any mammal. Recently these viruses were shown to circulate naturally in humans in South America [147]. The clinical symptoms in humans usually go unnoticed, but in serious cases symptoms include high fever, nausea, headache, rigidity, delirium, vomiting, photophobia, and pleocytosis.

These viruses are able to induce the rapid onset of diabetes in mice. Two main variants of encephalomyocarditis virus have been determined: the nondiabetogenic variant encephalomyocarditis virus- $\mathrm{B}$ and the diabetogenic variant encephalomyocarditis virus-D, both with tropism for pancreatic $\beta$-cells. There are differences in 14 nucleotides and in the 776th amino acid, alanine (Ala-776), of the encephalomyocarditis virus polyprotein, located at major capsid protein VP1. These changes are seen only among all diabetogenic variants. In contrast, threonine in this position (Thr-776) is observed particularly in all nondiabetogenic viruses. The tyrosine kinase- 2 gene expression prevented beta cell destruction by encephalomyocarditis virus-D in knockout mice [148]. The prevention of macrophage-related cell destruction was shown to be induced by knocking out the tyrosine kinase pathway.

8.2. Human parechoviruses. Both species Human parechovirus (some of which are former echovirus serotypes) and Ljungan virus which belong to genus Parechovirus have been implicated in the development of T1D [113]. These viruses can naturally infect bank voles but are also known to cause infections in humans. TID was described in the animals after one month of observation in the laboratory. The symptoms were persistent hyperglycemia with weight loss, ketosis, and hyperlipidemia as well as specific $\beta$-cell destruction associated with signs of autoimmunity (increased levels of autoantibodies to glutamic acid decarboxylase65, autoantigen IA-2 (islet cell antigen 512), and insulin). The disease was correlated with Ljungan virus antibodies. Antibodies to Ljungan virus have been shown in children with onset of T1D and a possible zoonotic infection has been proposed [149]. The virus could be involved in T1D but more epidemiological and experimental studies are required to elucidate the mechanisms involved.

8.3. Enteric Cytopathic Human Orphan Viruses. These viruses, commonly referred to as echoviruses, belong to genus Enterovirus, Enterovirus B species. An enteric cytopathic human orphan virus strain isolated from a 6-week-old baby suffering from acute T1D [114] was shown to be more destructive in human islets in vitro than the echovirus 9 and 30 other prototype strains [150]. Cabrera-Rode et al. [151] detected the presence of insulin antibodies, glutamic acid decarboxylase antibodies, and autoantigen IA-2 (islet cell antigen 512) in the serum indicating that the islet cell autoimmunity was associated with infection in the year 2003 aseptic-meningitis Cuban epidemic caused by echovirus 16. During an echovirus 30 epidemic in Cuba, Cabrera-Rode et al. [152] reported the case of an adolescent who developed pancreatic autoantibodies (ICA and IA2A) 


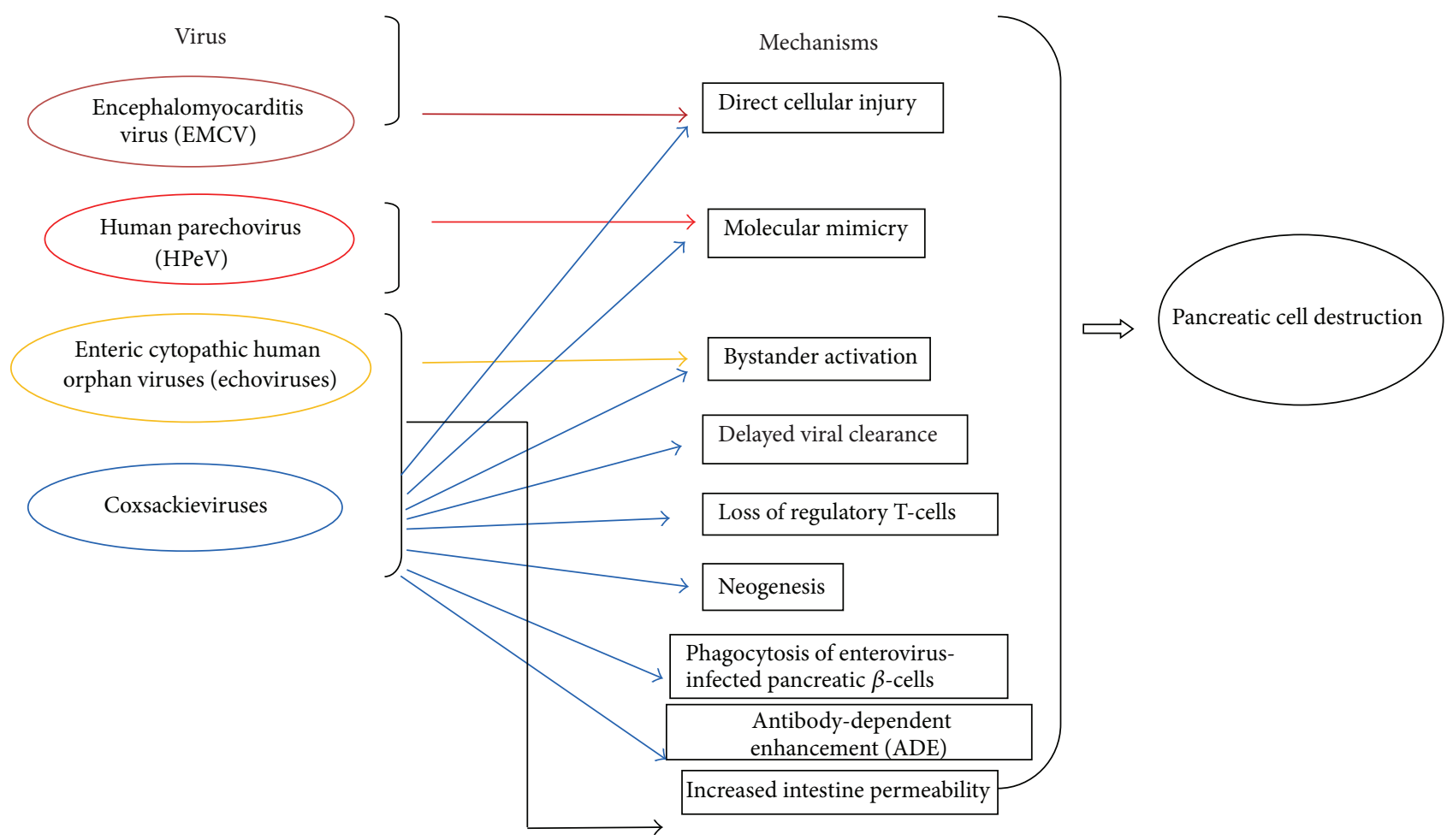

Figure 2: Putative mechanisms suggested for the induction by members of the family Picornaviridae. (Viruses linked to the induction of T1D in experimental animals (natural nonhuman hosts) or through clinical studies, having a potential to infect humans in rare conditions.) Factors influencing the mechanisms involved in the beta cell destruction by these viruses. (a) Genes related to infection putatively influencing the mechanisms: HLA-DR, melanoma differentiation-associated protein-5, and interferon induced helicase 1. (b) Innate immunity: interferons, tumor necrosis factor, and interleukins. (c) T- and B-lymphocytes, viral antibodies, islet cell antibodies, glutamic acid decarboxylase antibodies, antibody against insulin, and tyrosine phosphatase-related IA2-A antibodies.

and T1D after infection. Diaz-Horta et al. [153] provide a list of autoantibodies produced following various echovirus infection. In short, islet cell autoantibodies were related to echoviruses 3, 6, 9, 16, and 30. Glutamic acid decarboxylase65 was related to echoviruses 6 and 16; autoantigen IA-2 (islet cell antigen 512) was linked to echoviruses 3 and 16; and insulin antibodies were related to echoviruses 9 and 16 $[114,116,151,152,154-156]$. The published literature shows strong association between echoviruses and T1D onset.

8.4. Coxsackieviruses. Coxsackieviruses belong to the genus Enterovirus, species Enterovirus $A$ and Enterovirus $B$. The coxsackievirus type $B$ consists of 6 serotypes that have been investigated in vivo and in vitro to establish association with chronic diseases since an early report of a link among coxsackievirus infections, myocarditis [157], and T1D [158]. The most often studied enteroviruses are coxsackieviruses $\mathrm{B}$, as they have been diagnosed frequently from clinical samples of patients with T1D (or high risk thereof) compared to a healthy population. Several seroepidemiological studies have demonstrated that recent-onset diabetic patients had increased levels of coxsackievirus-specific antibodies or coxsackievirus-RNA compared to control populations [116, 159-161]. Sarmiento et al. [162] also found this correlation in Cuba, where the incidence of T1D is low [163] but coxsackieviral infections incidence is high. Coxsackievirus
B4 (CVB4) has also been directly isolated from the pancreas autopsy of a recent-onset T1D patient [164].

8.5. Enteroviral Mechanisms for T1D Predisposition or Protection. Coxsackieviruses are under intense scrutiny after the first isolation reported in 1979 [164]. They have been demonstrated to accelerate diabetes in genetically susceptible mouse models [117, 118, 165-167]. Different in vivo and in vitro coxsackievirus models are described in Table 5. Prospective and cross-sectional studies of patients published in the year 2014, from Finland, England, France, Greece, and Sweden, $[168,169]$ showed two different mechanisms within the different serotypes of coxsackieviruses. One was destructive and the other protective, consistent with results from the nonobese diabetic (NOD) mouse model of coxsackievirus Bassociated T1D. Coxsackievirus B1 (CVB1) was shown to be related to autoimmune destruction of pancreatic $\beta$-cells. They have shown that virus neutralizing antibodies appeared only a few months before the autoantibodies and were related to the presence of maternal antibody modification, whereas the other prevalent viruses CVB3 and CVB6 showed a protective effect.

Experimental in vivo and in vitro models show protection or destruction of the pancreatic islets and the endocrine function in response to virus infection. In these models the influencing factors in vivo are the host's age at the time of 
infection, host and virus genetics, and dose of infection. In our experimental coxsakievirus serotype B4 strain E2 (CVB4-E2) infection model using outbred gravid mice [170], we showed gross infiltration of the endocrine pancreas and glycemia in the virus-challenged pups weaned from dams infected at the 1st and 3rd weeks of gestation. Another group showed that maternal infection conferred protection to the offspring from diabetes in a transgenic Socsl- $t g$ mouse model, with nonobese diabetic (NOD) genetic background [171]. Evidence indicated that the time of infection during the pregnancy and age of the pups at time of challenge are important factors. To determine the conditions for protective or destructive outcomes further studies are required to elucidate the mechanisms.

8.6. Coxsackievirus In Vitro Studies. Coxsackievirus serotypes have been shown to replicate and destroy human $\beta$ cells $[150,172,173]$ and mouse islet $\beta$-cells $[174]$ in vitro. Prolonged persistence of the virus in human pancreatic islet cells has also been shown in vitro $[126,175]$. Rodent $\beta$-cells are resistant to metabolic disturbances caused by the prototype strain CVB4 [115, 176, 177]. Porcine endocrine cells have also been used as models for virus infection and for studying the pathogenesis of T1D [176] (due to their cost). Porcine islet cells are susceptible to virus-induced impairment but are relatively resistant to oxidative, toxins, and cytokine-induced damage [178]. Direct cytolysis of the islet cells which involves infection of the $\beta$-cells, replication of the virus resulting in lysis of the cells, depends on the genetics of the virus.

\subsection{Coxsackieviruses in Human Samples of T1D. Coxsackie B} viruses were linked to T1D when a coxsackievirus B4 (CVB4) strain was isolated from the pancreas during the autopsy of a 10 -year-old child who had died from diabetic ketoacidosis. In the pancreatic tissue necrosis of $\beta$-cells with infiltration of lymphocytes was seen. Inoculation of mice with the viral isolate resulted in hyperglycemia on day 5 after infection and inflammation of the islets of Langerhans and necrosis to day 14 after infection only in SJL mice after two passages of the virus in vivo [164].

There is also serological evidence in pregnant women with coxsackievirus (incidence of anti-enteroviral antibodies in the sera of pregnant women) and subsequent development of T1D in the children [179-181]. There is however one report that does not support this finding [182]. These differences maybe related to the time of infection during gestation.

The enterovirus (EV) genome and antibodies against CVB1-B6 can be found in sera of prediabetic children several years before the onset of diabetic symptoms, which have been associated with induction of autoimmunity. Studies of sera from newly diagnosed diabetics have revealed increased levels of anti-EV neutralizing antibodies (as compared with controls) [183-186] and elevated T-cell responses to coxsackievirus antigen [187].

Numerous researchers have detected antiviral antibodies and viral-RNA in blood/serum/peripheral blood mononuclear cells by PCR, sequencing methods, or in tissues of postmortem pancreatic specimens with in situ hybridization and identification of viral proteins by immunohistochemical staining from T1D patients.

Enteroviral-RNA was associated with an increase in antibodies against islet cells (ICA) and glutamic acid decarboxylase (GAD) $[116,162]$ as well as antibodies against insulin (IAA) or the tyrosine phosphatase-related IA-2 protein (IA2) [188]. The enteroviral infections are prevalent in children who became positive for $\beta$-cell autoantibodies compared to healthy controls [116, 160, 162, 188-190].

Enteroviral-RNA has also been shown in the whole blood of patients at the onset or during the course of T1D but was not shown in healthy subjects and patients with T2D. Sequencing of circulating enteroviral-RNAs in T1D patients has confirmed systemic viral coxsackievirus infection [159]. In another study, the presence of IFN- $\alpha$ mRNA was detected by reverse transcriptase polymerase chain reaction (RT-PCR) in whole blood and sera of the T1D patients but in none of controls. Enteroviral-RNA was detected in patients' blood samples with IFN- $\alpha$ but not in patients without any IFN- $\alpha$. Circulating enterovirus-RNA was sequenced by Chehadeh et al. [97]. Enteroviral-RNA in blood spots (taken on days 2-4 after birth for screening analysis of inherited metabolic diseases) showed increased prevalence of enteroviral-RNA in children preceding the T1D [191]. Coxsackievirus B4-specific RNA was found in the sera of diabetic children [186, 192, 193] and a significant proportion of diabetic children with a positive RT-PCR were even less than one year old $[194,195]$. In the peripheral blood mononuclear cells enteroviral-RNA was detected by RT-PCR [196] and enteroviral capsid antigens were detected by immunofluorescence [197]. Prolonged enterovirus infections could be found in patients who were positive for the detection of viral-RNA in peripheral blood mononuclear cells and/or plasma together with the absence of viral-RNA in stool and throat swabs [198].

Enteroviral-RNA is commonly found in stool samples of T1D children $[190,199,200]$, but a direct connection to the onset of T1D and acute coxsackievirus infection and the presence of enterovirus in the stool remains uncertain.

Different virological methods have been used to determine whether enteroviruses can be found in small intestinal mucosa of T1D patients undergoing intestinal biopsies. ViralRNA was found by RT-PCR in a frozen sample. In these samples protein VP1 was localized in the epithelium by immunohistochemistry and enteroviral-RNA was detected by in situ hybridization in the cells of lamina propria [122].

Enterovirus-positive cells have been detected in numerous pancreatic islets and some duct cells with nondestructive insulitis and natural killer cell infiltration but were not seen in the exocrine pancreas [201]. Using electron microscopy Dotta et al. [202] observed viral inclusions and signs of pyknosis and loss of $\beta$-cell function. In different studies using immunohistochemistry for VP1 protein was demonstrated in endocrine cells of the pancreatic islets during autopsies of diabetic children [119, 202-204]. Although the enteroviruses have been found in the pancreatic islets of patients with recent-onset of diabetes $[202,204,205], \beta$-cell destruction in patients with fatal diabetes was not a direct outcome of 
the virus-mediated cytopathic effect. Viruses induce $\beta$-cells destruction through an autoimmunity mechanism.

\section{Viruses: Mechanism of Protection Hypothesis}

Type 1 diabetes cases are increasing worldwide, especially in highly industrialized countries and urban regions. Such statistics have given rise to the "hygiene hypothesis" which was originally proposed to explain increases in asthma and allergic diseases [206]. Since the year 1989, the hygiene hypothesis has also been suggested as an explanation of increased rates of other autoimmune diseases including T1D [207]. A lack of exposure to a wide range of infectious agents in industrialized or developed countries is presumed to increase the rates of some diseases especially those which are transmitted by the fecal-oral route. While the incidence of various infectious diseases has decreased over the last few decades, the occurrence of autoimmune disorders has increased rapidly [207]. Several authors have discussed the protective effect of the enteroviruses on T1D [208-211]. Serological and epidemiological studies and in vivo/in vitro models indicate that the effect of virus on the pancreatic islet cells affliction/protection depends on several factors.

\section{Viruses: Mechanism of $\beta$-Cells Destruction}

Enterovirus infections often go unnoticed, and humans may be infected several times during their lifetime with different enteroviruses. Recent studies show that viral-RNA may persist over a long period of time. These viruses have a wide range of tropism, they induce interferons, their teratogenic character is vague as compared with other viruses, and they may cause multiple infections and immune imbalances in the defence system. Epigenetics and other factors such as age of host at the time of infection, multiple infections, maternal infections, circulating viruses genetics, and a combination of other factors have resulted in different/controversial opinions. The actual mechanism could be a destructive pathway which is a combination of different factors. One has to consider that the methodologies applied here are for detection of RNAs or for analyzing viral genome persistence. In situ hybridization and VP1 detection need standardized methodology. Different mechanisms related to enterovirus are described below.

10.1. Direct Cellular Injury. Human and prototype laboratory coxsackieviruses A and B strains can infect mouse islet cells in vitro [174]. In addition, human islet $\beta$-cell infection in vitro and its destruction by enteroviruses and clinical isolates have been recorded [85, 150, 212-215]. Pathogens, mainly viruses that infect pancreatic islet cells, may induce T1D through direct cytopathic effects and cause destruction of the insulin-secreting $\beta$-cells by cytolysis; enteroviruses are known to be highly cytolytic $[172,216]$. Direct infection causes disruption of cells and release of autoantigens which activate the innate and adaptive immune systems. The ensuing inflammation and development of autoimmune reactions further contribute to $\beta$-cell destruction and T1D.

10.2. Delayed Viral Clearance. Delayed viral clearance is based on evidence that individuals with high genetic risk for T1D have impaired defence mechanisms against virus clearance [217]. Virus persistence in the pancreatic $\beta$-cells can result in the induction of autoimmunity. In enterovirusinfected individuals the viremia is short, yet enteroviralRNA has been found in the blood of patients with newly diagnosed T1D which may be a result of prolonged enteroviral persistence in blood cells [198]. Enteroviruses detected at the onset of T1D were not found in plasma but were present in peripheral blood mononuclear cells. The viruses might use monocytes and/or lymphocytes as viral reservoirs and vehicles for viral dissemination [218]. T-cells from diabetic patients show reduced activation and cytokine production when challenged in vitro with coxsackievirus B4 [217]. Patients with coxsackievirus infection with insufficient immune response to provide total protection, maybe at a high risk of delayed virus clearance, viral persistence, and increased pancreatic islet damage, are high risk patients. Many T1D patients show detectable levels of viral-RNA suggesting that a delayed clearance may be more relevant than viral persistence to the progression of T1D [116].

10.3. Molecular Mimicry. Molecular mimicry is based on the observation that some microbial/viral proteins and host proteins have sequence or structural homology and therefore go unrecognized as self-proteins. A normal immune response against the viral antigen becomes cross-reactive against the homologous sequence of the $\beta$-cells host protein [219]. Glutamic acid decarboxylase-65 (GAD65) expressed in pancreatic $\beta$-cells is the important islet cell autoantigen which can be recognized as nonself in T1D [114]. There is a structural similarity between $\mathrm{P} 2-\mathrm{C}$ protein sequence of CVB and an epitope derived from the humans and NOD mice, the GAD65 [220]. Therefore, both autoreactive and antiviral T-cells activated upon CVB infection might act as strong enhancers of the autoimmune process. Enteroviral infections can activate the antienteroviral T-lymphocytes which, via cross-reactivity, contribute to the damage of $\beta$-cells persistently infected by another enterovirus [154]. Some in vivo and in vitro studies $[118,221,222]$ do not support the theory of molecular mimicry due to lack of cross-reacting glutamic acid decarboxylase epitopes and viral antigens.

10.4. Bystander Activation. Infection of cells neighboring the $\beta$-cells (e.g., ductal cells) may stimulate local inflammation. As a consequence CD8+ T-cells and inflammatory cells (macrophages) release cytokines such as tumor necrosis factor alpha, lymphotoxin, and nitric oxide, which can lead to bystander killing of $\beta$-cells [223]. The inflammation provokes cell damage and release of segregated antigens. Through bystander activation the T-lymphocytes directed against these self-antigens are responsible for pancreatic islet destruction and T1D development [224-226]. Diabetes 
develops when the damage gets out of control. In contrast to molecular mimicry, initial tissue injury via bystander activation is not antigen specific as the T-cells have not been shown to respond to the coxsackievirus. The injury is due to inflammation via the bystander activation of cells [118]. Viral infection can also lead to the activation of antigen-presenting cells, namely, dendritic cells (DCs). Activated APCs then increase T-helper density at the site of infection/inflammation [227]. Horwitz et al. [228] and Serreze et al. [117] suggested that the number of autoreactive T-cells is important for T1D induction after coxsackievirus B4 infection for initiation of bystander activation.

10.5. Antibody-Dependent Enhancement (ADE) of Enterovirus Infection. Antibodies are essential in limiting, clearing, and influencing the severity of enteroviral infections. This mechanism is mediated by anti-coxsackievirus antibodies lacking neutralizing activity. These antibodies bind to the cell surface membrane of the monocytes/macrophages via the coxsackieadenovirus receptor (CAR) and increase the replication of CVB4 in the cells. The infected monocytes/macrophages help virus dissemination in the host, as well as viral replication target sites enhancing pathological responses, known as antibody-dependent enhancement. This pathological severity was shown to be enhanced (in vitro) when plasma or IgG from patients with T1D was used as compared to those of healthy individuals [229]. Coxsackievirus B4 induces interferon- $\alpha$ in peripheral blood mononuclear cells in vitro $[230,231]$, and chronic IFN- $\alpha$ synthesis or its abnormal activation can be associated with disorders leading to autoimmune diseases [97]. These antibodies target the EV-protein VP4 and it has been shown that the prevalence and anti-VP4 antibody titres are in higher concentrations in patients with T1D than those in control subjects $[232,233]$.

10.6. Phagocytosis of Enterovirus-Infected Pancreatic $\beta$-Cells. Another suggested mechanism in which virus infected islets may affect the local immune balance has been shown in vitro in human islets [120] where coxsackievirus-infected islets were efficiently phagocytosed by human monocytederived dendritic cells. Phagocytosis induces an antiviral state that protects dendritic cells from subsequent coxsackievirus infection. This antiviral state of protected dendritic cells depends on the presence of intracellular viral-RNA in the coxsackievirus-infected cells and type 1 interferons produced by the dendritic cells. It has been suggested that these virusinduced effects may alter dendritic cells, therefore influencing the development of regulatory T-cells and/or effector T-cell populations.

10.7. Loss of Regulatory T-Cells. The failure of immunological tolerance towards $\beta$-cell antigens after the T-cell and $\mathrm{B}$ cell maturation is due to abnormalities of the T-regulatory lymphocytes (Tregs) in the periphery. This occurs outside the primary lymphoid tissues along/only with the central tolerance and involves the thymus [234]. Coxsackievirus B4 replicates and persists in human thymic epithelial cells in vitro [121] as well as mouse in vitro and in vivo models [235, 236], which disturbs maturation/differentiation of T-lymphocytes. Enteroviral infection of thymus has been suggested to result in defective T-lymphocyte subpopulations which have been found in diabetic and prediabetic patients [237].

10.8. Increased Intestinal Permeability. Enteroviruses have been detected in small intestinal biopsies of T1D patients more frequently than in healthy controls, suggesting persistence of enterovirus infections and replication in the gut for prolonged periods [122]. Increased intestinal permeability as an outcome of prolonged infections, which could be associated with an increased susceptibility to T1D, has also been suggested [122, 238]. Enteroviral infections lead to changes in gut permeability and increased viral access to the pancreas allowing other environmental factors to modify T1D susceptibility.

10.9. Neogenesis. Pancreatic ductal cells can differentiate into functioning adult $\beta$-cell mass [239]. Normally a stable rate of recirculation of "apoptotic $\beta$-cell replacement" takes place during the differentiation of progenitor cells [240]. It has been suggested that coxsackievirus infections afflict $\beta$-cell neogenesis causing depletion of $\beta$-cell mass which would have a role in diabetes development [123].

\section{Conclusion}

The incidence of T1D has increased rapidly in recent years. Whether the increase is an outcome of synergistic influence(s) of different factors is unclear. The onset of T1D is a coordination of multiple factors. Several risk/protective elements are, however, associated with the incidence of T1D: family history, host genetics, immunological status, sex, age, obesity, ethnicity, and social group characteristics, as well as behavioral, lifestyle, psychological, and clinical factors. Furthermore the T1D process may start in the early neonatal stage or even in utero, and the environmental factors encountered in early childhood might also induce or accelerate the disease [155]. Among such influential conditions are exposure to intrauterine infections, nutrition, and consumption of toxic material. The time of exposure during gravidity and delivery conditions may also be relevant [241].

The genetic predisposition depends mainly on the MHC and non-MHC genes, which are proven major factors in favoring T1D induction. These genes direct the immune responses which are important in autoimmune diseases.

Suggested mechanisms for triggering T1D consider direct or indirect interaction of viruses and immune system in genetically predisposed individuals. Viruses may cause variation in certain genes of the MHC loci and may upregulate or dysregulate inflammatory or proinflammatory cytokines leading to destructive or protective effect on pancreatic islet cells. Numerous investigations on the pathogenesis of T1D and the involvement of viruses have been carried out. However, the onset of TID and the triggering factor/s and mechanisms involved remain unsolved. Together, various types of studies (observational and experimental) indicate 
that the mechanism of $\mathrm{T} 1 \mathrm{D}$ indication via genetic-viral interactions is complex.

\section{Conflict of Interests}

The authors declare that there is no conflict of interests regarding the publication of this paper.

\section{Authors' Contribution}

Jana Precechtelova wrote the primary draft; Maria Borsanyiova and Sona Sarmirova contributed to proofreading and editing; and Shubhada Bopegamage contributed to conception, reviewing, editing, and finalization. All authors have reviewed the final draft and agreed to the contents.

\section{Acknowledgments}

The authors thank the Norwegian financial support mechanism, Mechanism EEA, and Slovak Government, Project SK0082, and project of the Ministry of Health, Project MZSR 2006/13-SZU-08, both granted to Shubhada Bopegamage. They are grateful to Professor Steven Tracy, M.S., Ph.D., University of Nebraska Medical Centre, USA, for reading the document and for valuable suggestions. They appreciate the technical support of Ms. Brigita Benkoova (MSc student). They thank Bill Coleman of Far Out Books and Education/Pontiac, Michigan, USA, for editorial assistance.

\section{References}

[1] N. S. Papaspyros, "The history of diabetes," in The History of Diabetes Mellitus, G. T. Verlag, Ed., p. 4, Thieme, Stuttgart, Germany, 1964.

[2] http://www.crystalinks.com/egyptmedicine.html.

[3] J. Zajac, A. Shrestha, P. Patel, and L. Poretsky, "The main events in the history of diabetes mellitus," in Principles of Diabetes Mellitus, L. Poretsky, Ed., pp. 3-16, Springer, New York, NY, USA, 2nd edition, 2010.

[4] F. Allen, "Studies concerning diabetes", Journal of American Medical Association, vol. 63, pp. 939-943, 1914.

[5] http://www.nobelprize.org/nobel_prizes/medicine/.

[6] H. P. Himsworth, "The mechanism of diabetes mellitus," The Lancet, vol. 234, no. 6047, pp. 171-176, 1939.

[7] American Diabetes Association, "Standards of medical care in diabetes-2014," Diabetes Care, vol. 37, no. 1, pp. 14-80, 2014.

[8] World Health Organization, "Diagnostic criteria and classification of hyperglycaemia first detected in pregnancy," WHO/NMH/MND/13.2, World Health Organization, 2013.

[9] "Definition and diagnosis of diabetes mellitus and intermediate hyperglycaemia," Report of a WHO/IDF Consultation, 2006.

[10] W. Gepts, "Pathologic anatomy of the pancreas in juvenile diabetes mellitus.," Diabetes, vol. 14, no. 10, pp. 619-633, 1965.

[11] A. K. Foulis, C. N. Liddle, M. A. Farquharson, J. A. Richmond, and R. S. Weir, "The histopathology of the pancreas in type I (insulin-dependent) diabetes mellitus: a 25-year review of deaths in patients under 20 years of age in the United Kingdom," Diabetologia, vol. 29, no. 5, pp. 267-274, 1986.
[12] American Diabetes Association, "Diagnosis and classification of diabetes mellitus," Diabetes Care, vol. 36, no. 1, pp. 67-74, 2013.

[13] S. Baekkeskov, H.-J. Aanstoot, S. Christgau et al., "Identification of the $64 \mathrm{~K}$ autoantigen in insulin-dependent diabetes as the GABA-synthesizing enzyme glutamic acid decarboxylase," Nature, vol. 347, no. 6289, pp. 151-156, 1990.

[14] J. P. Palmer, C. M. Asplin, P. Clemons et al., "Insulin antibodies in insulin-dependent diabetics before insulin treatment," Science, vol. 222, no. 4630, pp. 1337-1339, 1983.

[15] E. Bonifacio, V. Lampasona, S. Genovese, M. Ferrari, and E. Bosi, "Identification of protein tyrosine phosphatase-like IA2 (islet cell antigen 512) as the insulin-dependent diabetes-related $37 / 40 \mathrm{~K}$ autoantigen and a target of islet-cell antibodies," The Journal of Immunology, vol. 155, no. 11, pp. 5419-5426, 1995.

[16] J. Lu, Q. Li, H. Xie et al., "Identification of a second transmembrane protein tyrosine phosphatase, IA- $2 \beta$, as an autoantigen in insulin-dependent diabetes mellitus: Precursor of the 37$\mathrm{kDa}$ tryptic fragment," Proceedings of the National Academy of Sciences of the United States of America, vol. 93, no. 6, pp. 23072311, 1996.

[17] M. Pietropaolo, L. Castaño, S. Babu et al., "Islet cell autoantigen $69 \mathrm{kD}$ (ICA69): molecular cloning and characterization of a novel diabetes-associated autoantigen," The Journal of Clinical Investigation, vol. 92, no. 1, pp. 359-371, 1993.

[18] L. Castaño, E. Russo, L. Zhou, M. A. Lipes, and G. S. Eisenbarth, "Identification and cloning of a granule autoantigen (carboxypeptidase-H) associated with type I diabetes," Journal of Clinical Endocrinology and Metabolism, vol. 73, no. 6, pp. 1197-1201, 1991.

[19] R. C. Nayak, M. A. Omar, A. Rabizadeh, S. Srikanta, and G. S. Eisenbarth, "“Cytoplasmic” islet cell antibodies. Evidence that the target antigen is a sialoglycoconjugate," Diabetes, vol. 34, no. 6, pp. 617-619, 1985.

[20] S. D. Arden, B. O. Roep, P. I. Neophytou et al., "Imogen 38: a novel $38-\mathrm{kD}$ islet mitochondrial autoantigen recognized by $\mathrm{T}$ cells from a newly diagnosed type 1 diabetic patient," The Journal of Clinical Investigation, vol. 97, no. 2, pp. 551-561, 1996.

[21] H. Kasimiotis, M. A. Myers, A. Argentaro et al., "Sexdetermining region Y-related protein SOX13 is a diabetes autoantigen expressed in pancreatic islets," Diabetes, vol. 49, no. 4, pp. 555-561, 2000.

[22] J. M. Wenzlau, K. Juhl, L. Yu et al., “The cation efflux transporter $\mathrm{ZnT} 8$ (Slc30A8) is a major autoantigen in human type 1 diabetes," Proceedings of the National Academy of Sciences of the United States of America, vol. 104, no. 43, pp. 17040-17045, 2007.

[23] T. Kimpimäki, A. Kupila, A.-M. Hämäläinen et al., "The first signs of $\beta$-cell autoimmunity appear in infancy in genetically susceptible children from the general population: the finnish type 1 diabetes prediction and prevention study," Journal of Clinical Endocrinology and Metabolism, vol. 86, no. 10, pp. 47824788, 2001.

[24] C. F. Verge, R. Gianani, E. Kawasaki et al., "Prediction of type I diabetes in first-degree relatives using a combination of insulin, GAD, and ICA512bdc/IA-2 autoantibodies," Diabetes, vol. 45, no. 3, pp. 926-933, 1996.

[25] G. F. Bottazzo, A. F. Christensen, and D. Doniach, "Islet cell antibodies in diabetes mellitus with autoimmune polyendocrine deficiencies," The Lancet, vol. 2, no. 7892, pp. 1279-1283, 1974.

[26] D. P. Singal and M. A. Blajchman, "Histocompatibility (HL-A) antigens, lymphocytotoxic antibodies and tissue antibodies in 
patients with diabetes mellitus," Diabetes, vol. 22, no. 6, pp. 429432, 1973.

[27] A. G. Cudworth and J. C. Woodrow, "Letter: HL-A antigens and diabetes mellitus," The Lancet, vol. 2, no. 7889, article 1153, 1974.

[28] L. Zhang and G. S. Eisenbarth, "Prediction and prevention of type 1 diabetes mellitus," Journal of Diabetes, vol. 3, no. 1, pp. 48-57, 2011.

[29] D. J. Smyth, J. D. Cooper, R. Bailey et al., "A genome-wide association study of nonsynonymous SNPs identifies a type 1 diabetes locus in the interferon-induced helicase (IFIH1) region," Nature Genetics, vol. 38, no. 6, pp. 617-619, 2006.

[30] Genomes Project Consortium, "A map of human genome variation from population-scale sequencing," Nature, vol. 467, no. 7319, pp. 1061-1073, 2010.

[31] I. Kockum, C. B. Sanjeevi, S. Eastman, M. Landin-Olsson, G. Dahlquist, and Å. Lernmark, "Complex interaction between HLA DR and DQ in conferring risk for childhood type 1 diabetes," European Journal of Immunogenetics, vol. 26, no. 5, pp. 361-372, 1999.

[32] B. P. C. Koeleman, B. A. Lie, D. E. Undlien et al., "Genotype effects and epistasis in type 1 diabetes and HLA-DQ trans dimer associations with disease," Genes and Immunity, vol. 5, no. 5, pp. 381-388, 2004.

[33] O. L. Griffith, S. B. Montgomery, B. Bernier et al., "ORegAnno: an open-access community-driven resource for regulatory annotation," Nucleic Acids Research, vol. 36, no. 1, pp. D107D113, 2008.

[34] J. K. Distefano and D. M. Taverna, “Technological issues and experimental design of gene association studies," Methods in Molecular Biology, vol. 700, pp. 3-16, 2011.

[35] H. A. Erlich, A. M. Valdes, S. L. McDevitt et al., "Next generation sequencing reveals the association of DRB3 $* 02: 02$ with type 1 diabetes," Diabetes, vol. 62, no. 7, pp. 2618-2622, 2013.

[36] G. D. Snell and G. F. Higgins, "Alleles at the histocompatibility2 locus in the mouse as determined by tumor transplantation," Genetics, vol. 36, no. 3, pp. 306-310, 1951.

[37] J. A. Noble and H. A. Erlich, "Genetics of type 1 diabetes," Cold Spring Harbor Perspectives in Medicine, vol. 2, no. 1, Article ID a007732, 2012.

[38] I. Santin and D. L. Eizirik, "Candidate genes for type 1 diabetes modulate pancreatic islet inflammation and $\beta$-cell apoptosis," Diabetes, Obesity and Metabolism, vol. 15, no. 3, pp. 71-81, 2013.

[39] The MHC sequencing consortium, "Complete sequence and gene map of a human major histocompatibility complex," Nature, vol. 401, no. 6756, pp. 921-923, 1999.

[40] B. Mach, V. Steimle, E. Martinez-Soria, and W. Reith, "Regulation of MHC class II genes: lessons from a disease," Annual Review of Immunology, vol. 14, pp. 301-331, 1996.

[41] V. Radha, K. S. Vimaleswaran, R. Deepa, and V. Mohan, "The genetics of diabetes mellitus," Indian Journal of Medical Research, vol. 117, pp. 225-238, 2003.

[42] H. A. Erlich, R. L. Griffith, T. L. Bugawan, R. Ziegler, C. Alper, and G. Eisenbarth, "Implication of specific DQB1 alleles in genetic susceptibility and resistance by identification of IDDM siblings with novel HLA-DQB1 allele and unusual DR2 and DR1 haplotypes," Diabetes, vol. 40, no. 4, pp. 478-481, 1991.

[43] D. J. Penn, "Major Histocompatibility Complex (MHC)," in Encyclopedia of Life Sciences, Macmillan Publishers Ltd, Nature Publishing Group, 2002.

[44] J. R. Gruen and S. M. Weissman, "Human MHC class III and IV genes and disease associations," Frontiers in Bioscience, vol. 6, pp. D960-D972, 2001.
[45] J. Bell, "Perinatal diagnosis current approaches and future trends," in Human Genetic Information: Science, Law and Ethics, CIBA Foundation Symposium 149, pp. 18-36, John Wiley \& Sons, Chichester, UK, 1990.

[46] R. Redon, S. Ishikawa, K. R. Fitch et al., "Global variation in copy number in the human genome," Nature, vol. 444, no. 7118, pp. 444-454, 2006.

[47] R. Tisch and H. McDevitt, "Insulin-dependent diabetes mellitus," Cell, vol. 85, no. 3, pp. 291-297, 1996.

[48] E.-P. Reich, H. von Grafenstein, A. Barlow, K. E. Swenson, K. Williams, and C. A. Janeway Jr., "Self peptides isolated from MHC glycoproteins of non-obese diabetic mice," The Journal of Immunology, vol. 152, no. 5, pp. 2279-2288, 1994.

[49] A. P. Lambert, K. M. Gillespie, G. Thomson et al., "Absolute risk of childhood-onset type 1 diabetes defined by human leukocyte antigen class II genotype: a population-based study in the United Kingdom," Journal of Clinical Endocrinology and Metabolism, vol. 89, no. 8, pp. 4037-4043, 2004.

[50] J. A. Noble, A. M. Valdes, M. Cook, W. Klitz, G. Thomson, and H. A. Erlich, "The role of HLA class II genes in insulin-dependent diabetes mellitus: Molecular analysis of 180 Caucasian, multiplex families," American Journal of Human Genetics, vol. 59, no. 5, pp. 1134-1148, 1996.

[51] J. C. Gorga and D. Monos, "HLA and disease: molecular basis," in MHC Molecules: Expression, Assembly and Function, J. C. Gorga, Ed., pp. 135-162, Springer eBook, R. G. Landes Company, Austin, Tex, USA, 1996.

[52] R. Horton, R. Gibson, P. Coggill et al., "Variation analysis and gene annotation of eight MHC haplotypes: the MHC Haplotype project," Immunogenetics, vol. 60, no. 1, pp. 1-18, 2008.

[53] D. F. Conrad, T. D. Andrews, N. P. Carter, M. E. Hurles, and J. K. Pritchard, "A high-resolution survey of deletion polymorphism in the human genome," Nature Genetics, vol. 38, no. 1, pp. 75-81, 2006.

[54] H. Beyan, R. C. Drexhage, L. V. D. H. Nieuwenhuijsen et al., "Monocyte gene-expression profiles associated with childhoodonset type 1 diabetes and disease risk: a study of identical twins," Diabetes, vol. 59, no. 7, pp. 1751-1755, 2010.

[55] C. Sapienza and J. G. Hall, "Genetic imprinting in human disease," in The Metabolic and Molecular Bases of Inherited Disease, C. R. Scriver, A. L. Beaudet, W. S. Sly, and D. Valle, Eds., vol. 1, chapter 7, pp. 437-458, McGraw-Hill, New York, NY, USA, 7 th edition, 1995.

[56] J. H. Warram, A. S. Krolewski, M. S. Gottlieb, and C. R. Kahn, "Differences in risk of insulin-dependent diabetes in offspring of diabetic mothers and diabetic fathers," The New England Journal of Medicine, vol. 311, no. 3, pp. 149-152, 1984.

[57] H. Tillil and J. Kobberling, "Age-corrected empirical genetic risk estimates for first-degree relatives of IDDM patients," Diabetes, vol. 36, no. 1, pp. 93-99, 1987.

[58] D. Bleich, M. Polak, G. S. Eisenbarth, and R. A. Jackson, "Decreased risk of type I diabetes in offspring of mothers who acquire diabetes during adrenarchy," Diabetes, vol. 42, no. 10, pp. 1433-1439, 1993.

[59] L. Yu, H. P. Chase, A. Falorni, M. Rewers, Å. Lernmark, and G. S. Eisenbarth, "Sexual dimorphism in transmission of expression of islet autoantibodies to offspring," Diabetologia, vol. 38, no. 11, pp. 1353-1357, 1995.

[60] C. Wallace, D. J. Smyth, M. Maisuria-Armer, N. M. Walker, J. A. Todd, and D. G. Clayton, "The imprinted DLK1-MEG3 gene region on chromosome $14 \mathrm{q} 32.2$ alters susceptibility to type 1 diabetes," Nature Genetics, vol. 42, no. 1, pp. 68-71, 2010. 
[61] V. K. Rakyan, H. Beyan, T. A. Down et al., "Identification of type 1 diabetes-associated DNA methylation variable positions that precede disease diagnosis," PLoS Genetics, vol. 7, no. 9, Article ID e1002300, 2011.

[62] J. Nerup, P. Platz, O. O. Andersen et al., "HL A antigens and diabetes mellitus," The Lancet, vol. 2, no. 7885, pp. 864-866, 1974.

[63] G. I. Bell, S. Horita, and J. H. Karam, "A polymorphic locus near the human insulin gene is associated with insulin-dependent diabetes mellitus," Diabetes, vol. 33, no. 2, pp. 176-183, 1984.

[64] L. Nisticò, R. Buzzetti, L. E. Pritchard et al., "The CTLA-4 gene region of chromosome $2 \mathrm{q} 33$ is linked to, and associated with, type 1 diabetes. Belgian diabetes registry," Human Molecular Genetics, vol. 5, no. 7, pp. 1075-1080, 1996.

[65] N. Bottini, L. Musumeci, A. Alonso et al., "A functional variant of lymphoid tyrosine phosphatase is associated with type I diabetes," Nature Genetics, vol. 36, no. 4, pp. 337-338, 2004.

[66] A. Vella, J. D. Cooper, C. E. Lowe et al., "Localization of a type 1 diabetes locus in the IL2RA/CD25 region by use of tag single-nucleotide polymorphisms," American Journal of Human Genetics, vol. 76, no. 5, pp. 773-779, 2005.

[67] M. Bakay, R. Pandey, and H. Hakonarson, "Genes involved in type 1 diabetes: an update," Genes, vol. 4, no. 4, pp. 499-521, 2013.

[68] S. Nejentsev, N. Walker, D. Riches, M. Egholm, and J. A. Todd, "Rare variants of $I F I H 1$, a gene implicated in antiviral responses, protect against type 1 diabetes," Science, vol. 324, no. 5925, pp. 387-389, 2009.

[69] M. Heinig, E. Petretto, C. Wallace, and S. A. Cook, "A transacting locus regulates an anti-viral expression network and type 1 diabetes risk," Nature, vol. 467, no. 7314, pp. 460-464, 2010.

[70] H. Hakonarson, S. F. A. Grant, J. P. Bradfield et al., "A genomewide association study identifies KIAA0350 as a type 1 diabetes gene," Nature, vol. 448, no. 7153, pp. 591-594, 2007.

[71] J. A. Todd, N. M. Walker, J. D. Cooper et al., "Robust associations of four new chromosome regions from genome-wide analyses of type 1 diabetes," Nature Genetics, vol. 39, no. 7, pp. 857-864, 2007.

[72] The Wellcome Trust Case Control Consortium, "Genome-wide association study of 14,000 cases of seven common diseases and 3,000 shared controls," Nature, vol. 447, no. 7145, pp. 661-678, 2007.

[73] J. D. Cooper, D. J. Smyth, A. M. Smiles et al., "Meta-analysis of genome-wide association study data identifies additional type 1 diabetes risk loci," Nature Genetics, vol. 40, no. 12, pp. 1399-1401, 2008.

[74] D. J. Smyth, V. Plagnol, N. M. Walker et al., "Shared and distinct genetic variants in type 1 diabetes and celiac disease," The New Englend Journal of Medicine, vol. 359, no. 26, pp. 2767-2777, 2008.

[75] J. C. Barrett, D. G. Clayton, P. Concannon et al., "Type 1 Diabetes Genetics Consortium. Genome-wide association study and meta-analysis find that over 40 loci affect risk of type 1 diabetes," Nature Genetics, vol. 41, no. 6, pp. 703-707, 2009.

[76] S. F. Grant, H. Q. Qu, J. P. Bradfield et al., "Follow-up analysis of genome-wide association data identifies novel loci for type 1 diabetes," Diabetes, vol. 58, no. 1, pp. 290-295, 2009.

[77] C. Wallace, D. J. Smyth, M. Maisuria-Armer, N. M. Walker, J. A. Todd, and D. G. Clayton, "The imprinted DLK1-MEG3 gene region on chromosome $14 \mathrm{q} 32.2$ alters susceptibility to type 1 diabetes," Nature Genetics, vol. 42, no. 1, pp. 68-71, 2010.
[78] J. P. Bradfield, H. Q. Qu, and K. Wang, "A genome-wide meta-analysis of six type 1 diabetes cohorts identifies multiple associated loci," PLoS Genetics, vol. 7, no. 9, Article ID e1002293, 2011.

[79] V. Plagnol, J. M. M. Howson, D. J. Smyth et al., "Genome-wide association analysis of autoantibody positivity in type 1 diabetes cases," PLoS Genetics, vol. 7, no. 8, Article ID e1002216, 2006.

[80] T. Bazzaz, M. M. Amoli, Z. Taheri et al., "TNF- $\alpha$ and IFN- $\gamma$ gene variation and genetic susceptibility to type 1 diabetes and its microangiopathic complications," Journal of Diabetes and Metabolic Disorders, vol. 13, p. 46, 2014.

[81] http://www.tldbase.org/page/Regions.

[82] W.-C. G. Yeung, W. D. Rawlinson, and M. E. Craig, "Enterovirus infection and type 1 diabetes mellitus: systematic review and meta-analysis of observational molecular studies," British Medical Journal, vol. 342, no. 7794, article d35, 2011.

[83] A. D. Paterson, "Genetic epidemiology of type 1 diabetes," Current Diabetes Reports, vol. 6, no. 2, pp. 139-146, 2006.

[84] Y.-H. Qiu, F.-Y. Deng, M.-J. Li, and S.-F. Lei, "Identification of novel risk genes associated with type 1 diabetes mellitus using a genome-wide gene-based association analysis," Journal of Diabetes Investigation, 2014.

[85] C. J. Fox and J. S. Danska, "Independent genetic regulation of T-cell and antigen-presenting cell participation in autoimmune islet inflammation," Diabetes, vol. 47, no. 3, pp. 331-338, 1998.

[86] P. L. Kendall, G. Yu, E. J. Woodward, and J. W. Thomas, "Tertiary lymphoid structures in the pancreas promote selection of B lymphocytes in autoimmune diabetes," The Journal of Immunology, vol. 178, no. 9, pp. 5643-5651, 2007.

[87] A. Willcox, S. J. Richardson, A. J. Bone, A. K. Foulis, and N. G. Morgan, "Analysis of islet inflammation in human type 1 diabetes," Clinical and Experimental Immunology, vol. 155, no. 2, pp. 173-181, 2009.

[88] T. Habib, A. Funk, M. Rieck et al., "Altered B cell homeostasis is associated with type I diabetes and carriers of the PTPN22 allelic variant," The Journal of Immunology, vol. 188, no. 1, pp. 487-496, 2012.

[89] W. S. Thompson, M. Pekalski, H. Z. Simons et al., "Multiparametric flow cytometric and genetic investigation of peripheral B-cell compartment in human type 1 diabetes," Clinical and Experimental Immunology, vol. 177, no. 3, pp. 571-585, 2014.

[90] M. Yang, K. Rui, S. Wang, and L. Lu, "Regulatory B cells in autoimmune diseases," Cellular and Molecular Immunology, vol. 10, no. 2, pp. 122-132, 2013.

[91] K. Schroder, P. J. Hertzog, T. Ravasi, and D. A. Hume, "Interferon- $\gamma$ : an overview of signals, mechanisms and functions," Journal of Leukocyte Biology, vol. 75, no. 2, pp. 163-189, 2004.

[92] http://www.phgfoundation.org/news/4515.

[93] C. Guiducci, M. Gong, Z. Xu et al., "TLR recognition of self nucleic acids hampers glucocorticoid activity in lupus," Nature, vol. 465, no. 7300, pp. 937-941, 2010.

[94] A. Rabinovitch, "An update on cytokines in the pathogenesis of insulin-dependent diabetes mellitus," Diabetes/Metabolism Reviews, vol. 14, no. 2, pp. 129-151, 1998.

[95] A. K. Foulis, M. A. Farquharson, and A. Meager, "Immunoreactive $\alpha$-interferon in insulin-secreting $\beta$ cells in type 1 diabetes mellitus," The Lancet, vol. 2, no. 8573, pp. 1423-1427, 1987.

[96] G. C. Toms, P. Baker, and B. J. Boucher, "The production of immunoreactive $\alpha$ - and $\gamma$-interferon by circulating mononuclear cells in type 1 diabetes," Diabetic Medicine, vol. 8, no. 6, pp. 547-550, 1991. 
[97] W. Chehadeh, J. Kerr-Conte, F. Pattou et al., "Persistent infection of human pancreatic islets by coxsackievirus B is associated with alpha interferon synthesis in $\beta$ cells," Journal of Virology, vol. 74, no. 21, pp. 10153-10164, 2000

[98] X. Li, S. Leung, S. Qureshi, J. E. Darnell Jr., and G. R. Stark, "Formation of STAT1-STAT2 heterodimers and their role in the activation of IRF-1 gene transcription by interferon- $\alpha$," The Journal of Biological Chemistry, vol. 271, no. 10, pp. 5790-5794, 1996.

[99] A. Takaoka, Y. Mitani, H. Suemori et al., "Cross talk between interferon $-\gamma$ and $-\alpha / \beta$ signaling components in caveolar membrane domains," Science, vol. 288, no. 5475, pp. 2357-2360, 2000.

[100] M. Giroux, M. Schmidt, and A. Descoteaux, "IFN- $\gamma$-induced MHC class II expression: transactivation of class II transactivator promoter IV by IFN regulatory factor-1 is regulated by protein kinase C- $\alpha$," The Journal of Immunology, vol. 171, no. 8, pp. 4187-4194, 2003.

[101] K. Lind, S. J. Richardson, P. Leete, N. G. Morgan, O. Korsgren, and M. Flodström-Tullberga, "Induction of an antiviral state and attenuated coxsackievirus replication in type III interferontreated primary human pancreatic islets," Journal of Virology, vol. 87, no. 13, pp. 7646-7654, 2013.

[102] C. Y. Pak, R. G. McArthur, H.-M. Eun, and J.-W. Yoon, "Association of cytomegalovirus infection with autoimmune type 1 diabetes," The Lancet, vol. 332, no. 8601, pp. 1-4, 1988.

[103] H. S. Hiemstra, N. C. Schloot, P. A. van Veelen et al., "Cytomegalovirus in autoimmunity: T cell crossreactivity to viral antigen and autoantigen glutamic acid decarboxylase," Proceedings of the National Academy of Sciences of the United States of America, vol. 98, no. 7, pp. 3988-3991, 2001.

[104] M. Sester, U. Sester, B. C. Gärtner, M. Girndt, A. Meyerhans, and H. Köhler, "Dominance of virus-specific CD8 T cells in human primary cytomegalovirus infection," Journal of the American Society of Nephrology, vol. 13, no. 10, pp. 2577-2584, 2002.

[105] A. Kasuga, R. Harada, and T. Saruta, "Insulin-dependent diabetes mellitus associated with parvovirus B19 infection," Annals of Internal Medicine, vol. 125, no. 8, pp. 700-701, 1996.

[106] P. Vigeant, H. A. Menard, and G. Boire, "Chronic modulation of the autoimmune response following parvovirus B19 infection," Journal of Rheumatology, vol. 21, no. 6, pp. 1165-1167, 1994.

[107] M. C. Honeyman, N. L. Stone, B. A. Falk, G. Nepom, and L. C. Harrison, "Evidence for molecular mimicry between human T cell epitopes in rotavirus and pancreatic islet autoantigens," Journal of Immunology, vol. 184, no. 4, pp. 2204-2210, 2010.

[108] F. Ginsberg-Fellner, M. E. Witt, S. Yagihashi et al., "Congenital rubella syndrome as a model for Type 1 (insulin-dependent) diabetes mellitus: increased prevalence of islet cell surface antibodies," Diabetologia, vol. 27, no. 1, pp. 87-89, 1984.

[109] D. Ou, L. A. Mitchell, D. L. Metzger, S. Gillam, and A. J. Tingle, "Cross-reactive rubella virus and glutamic acid decarboxylase (65 and 67) protein determinants recognised by $\mathrm{T}$ cells of patients with type I diabetes mellitus," Diabetologia, vol. 43, no. 6, pp. 750-762, 2000.

[110] M. G. Cavallo, M. G. Baroni, A. Toto et al., "Viral infection induces cytokine release by beta islet cells," Immunology, vol. 75, no. 4, pp. 664-668, 1992.

[111] H. Hyoty, P. Parkkonen, M. Rode, O. Bakke, and P. Leinikki, "Common peptide epitope in mumps virus nucleocapsid protein and MHC class II-associated invariant chain," Scandinavian Journal of Immunology, vol. 37, no. 5, pp. 550-558, 1993.

[112] B. Conrad, R. N. Weissmahr, J. Böni, R. Arcari, J. Schüpbach, and B. Mach, "A human endogenous retroviral superantigen as candidate autoimmune gene in type I diabetes," Cell, vol. 90, no. 2, pp. 303-313, 1997.

[113] G. Tapia, O. Cinek, T. Rasmussen, B. Grinde, L. C. Stene, and K. S. Rønningen, "Longitudinal study of parechovirus infection in infancy and risk of repeated positivity for multiple islet autoantibodies: the MIDIA study," Pediatric Diabetes, vol. 12, no. 1, pp. 58-62, 2011.

[114] G. R. Vreugdenhil, N. C. Schloot, A. Hoorens et al., "Acute onset of type I diabetes mellitus after severe echovirus 9 infection: putative pathogenic pathways," Clinical Infectious Diseases, vol. 31, no. 4, pp. 1025-1031, 2000.

[115] J. W. Yoon, T. Onodera, and A. L. Notkins, "Virus-induced diabetes mellitus. XV. Beta cell damage and insulin-dependent hyperglycemia in mice infected with coxsackie virus B4," The Journal of Experimental Medicine, vol. 148, no. 4, pp. 1068-1080, 1978.

[116] M. Lonnrot, K. Salminen, and M. Knip, "Enterovirus RNA in serum is a risk factor for beta-cell autoimmunity and clinical type 1 diabetes: a prospective study. Childhood Diabetes in Finland (DiMe) Study Group," Journal of Medical Virology, vol. 61, no. 2, pp. 214-220, 2000.

[117] D. V. Serreze, E. W. Ottendorfer, T. M. Elliss, C. J. Gauntt, and M. A. Atkinson, "Acceleration of type 1 diabetes by a coxsackievirus infection requires a preexisting critical mass of autoreactive Tcells in pancreatic islets," Diabetes, vol. 49, no. 5, pp. 708-711, 2000.

[118] M. S. Horwitz, L. M. Bradley, J. Harbertson, T. Krahl, J. Lee, and N. Sarvetnick, "Diabetes induced by Coxsackie virus: initiation by bystander damage and not molecular mimicry," Nature Medicine, vol. 4, no. 7, pp. 781-785, 1998.

[119] A. Willcox, S. J. Richardson, A. J. Bone, A. K. Foulis, and N. G. Morgan, "Immunohistochemical analysis of the relationship between islet cell proliferation and the production of the enteroviral capsid protein, VP1, in the islets of patients with recent-onset type 1 diabetes," Diabetologia, vol. 54, no. 9, pp. 2417-2420, 2011.

[120] B. M. Schulte, M. Kramer, M. Ansems et al., "Phagocytosis of enterovirus-infected pancreatic $\beta$-cells triggers innate immune responses in human dendritic cells," Diabetes, vol. 59, no. 5, pp. 1182-1191, 2010.

[121] F. Brilot, V. Geenen, D. Hober, and C. A. Stoddart, "Coxsackievirus B4 infection of human fetal thymus cells," Journal of Virology, vol. 78, no. 18, pp. 9854-9861, 2004.

[122] M. Oikarinen, S. Tauriainen, T. Honkanen et al., "Detection of enteroviruses in the intestine of type 1 diabetic patients," Clinical and Experimental Immunology, vol. 151, no. 1, pp. 71-75, 2008.

[123] I. S. Yap, G. Giddings, E. Pocock, and J. K. Chantler, "Lack of islet neogenesis plays a key role in beta-cell depletion in mice infected with a diabetogenic variant of coxsackievirus B4," Journal of General Virology, vol. 84, no. 11, pp. 3051-3068, 2003.

[124] K. P. Ward, W. H. Galloway, and I. A. Auchterlonie, "Congenital cytomegalovirus infection and diabetes," The Lancet, vol. 1, no. 8114, article 497, 1979.

[125] C. Y. Pak, C. Y. Cha, R. V. Rajotte, R. G. McArthur, and J. W. Yoon, "Human pancreatic islet cell specific 38 kilodalton autoantigen identified by cytomegalovirus-induced monoclonal islet cell autoantibody," Diabetologia, vol. 33, no. 9, pp. 569-572, 1990.

[126] K. Numazaki, H. Goldman, I. Wong, and M. A. Wainberg, "Viral infection of human fetal islets of Langerhans. Replication of human cytomegalovirus in cultured human fetal pancreatic 
islets," American Journal of Clinical Pathology, vol. 90, no. 1, pp. 52-57, 1988.

[127] M. J. Smelt, M. M. Faas, B. J. de Haan et al., "Rat pancreatic beta cells and cytomegalovirus infection," Pancreas, vol. 39, no. 1, pp. 47-56, 2010.

[128] J. Aarnisalo, R. Veijola, R. Vainionpää, O. Simell, M. Knip, and J. Ilonen, "Cytomegalovirus infection in early infancy: risk of induction and progression of autoimmunity associated with type 1 diabetes," Diabetologia, vol. 51, no. 5, pp. 769-772, 2008.

[129] S.-A. Ivarsson, B. Lindberg, K. O. Nilsson, K. Ahlfors, and L. Svanberg, "The prevalence of type 1 diabetes mellitus at follow-up of Swedish infants congenitally infected with cytomegalovirus," Diabetic Medicine, vol. 10, no. 6, pp. 521-523, 1993.

[130] A. K. Foulis, M. McGill, M. A. Farquharson, and D. A. Hilton, "A search for evidence of viral infection in pancreases of newly diagnosed patients with IDDM," Diabetologia, vol. 40, no. 1, pp. 53-61, 1997.

[131] N. Itoh, T. Hanafusa, K. Yamagata et al., "No detectable cytomegalovirus and Epstein-Barr virus genomes in the pancreas of recent-onset IDDM patients," Diabetologia, vol. 38, no. 6, pp. 667-671, 1995.

[132] Y. Munakata, T. Kodera, T. Saito, and T. Sasaki, "Rheumatoid arthritis, type 1 diabetes, and Graves' disease after acute parvovirus B19 infection," The Lancet, vol. 366, no. 9487, article 780, 2005.

[133] A. von Poblotzki, C. Gerdes, U. Reischl, H. Wolf, and S. Modrow, "Lymphoproliferative responses after infection with human parvovirus B19," Journal of Virology, vol. 70, no. 10, pp. 7327$7330,1996$.

[134] D. Zipris, J.-L. Hillebrands, R. M. Welsh et al., "Infections that induce autoimmune diabetes in BBDR rats modulate $\mathrm{CD} 4^{+} \mathrm{CD} 25^{+} \mathrm{T}$ cell populations," The Journal of Immunology, vol. 170, no. 7, pp. 3592-3602, 2003.

[135] D. Zipris, E. Lien, J. X. Xie, D. L. Greiner, J. P. Mordes, and A. A. Rossini, "TLR activation synergizes with Kilham rat virus infection to induce diabetes in BBDR rats," The Journal of Immunology, vol. 174, no. 1, pp. 131-142, 2005.

[136] M. C. Honeyman, B. S. Coulson, N. L. Stone et al., "Association between rotavirus infection and pancreatic islet autoimmunity in children at risk of developing type 1 diabetes," Diabetes, vol. 49, no. 8, pp. 1319-1324, 2000.

[137] K. L. Graham, N. Sanders, Y. Tan, J. Allison, T. W. H. Kay, and B. S. Coulson, "Rotavirus infection accelerates type 1 diabetes in mice with established insulitis," Journal of Virology, vol. 82, no. 13, pp. 6139-6149, 2008.

[138] J. A. Pane, N. L. Webster, and B. S. Coulson, "Rotavirus activates lymphocytes from non-obese diabetic mice by triggering tolllike receptor 7 signaling and interferon production in plasmacytoid dendritic cells ," PLoS Pathogens, vol. 10, no. 3, Article ID e1003998, 2014.

[139] E. A. M. Gale, "Congenital rubella: citation virus or viral cause of type 1 diabetes?” Diabetologia, vol. 51, no. 9, pp. 1559-1566, 2008.

[140] B. Lindberg, K. Ahlfors, A. Carlsson et al., "Previous exposure to measles, mumps, and rubella-but not vaccination during adolescence-correlates to the prevalence of pancreatic and thyroid autoantibodies," Pediatrics, vol. 104, no. 1, article e12, 1999.

[141] F. Ramondetti, S. Sacco, M. Comelli et al., "Type 1 diabetes and measles, mumps and rubella chilhood infections within the
Italian Insulin dependent diabetes regitstry," Diabetic Medicine, vol. 29, no. 6, pp. 761-766, 2011.

[142] P. Parkkonen, H. Hyoty, L. Koskinen, and P. Leinikki, "Mumps virus infects Beta cells in human fetal islet cell cultures upregulating the expression of HLA class I molecules," Diabetologia, vol. 35, no. 1, pp. 63-69, 1992.

[143] K. Helmke, A. Otten, and W. Willems, "Islet cell antibodies in children with mumps infection," The Lancet, vol. 2, no. 8187, pp. 211-212, 1980.

[144] H. Hyoty, M. Hiltunen, A. Reunanen et al., "Decline of mumps antibodies in type 1 (insulin-dependent) diabetic children and a plateau in the rising incidence of type 1 diabetes after introduction of the mumps-measles-rubella vaccine in Finland," Diabetologia, vol. 36, no. 12, pp. 1303-1308, 1993.

[145] R. Löwer, J. Löwer, and R. Kurth, “The viruses in all of us: characteristics and biological significance of human endogenous retrovirus sequences," Proceedings of the National Academy of Sciences of the United States of America, vol. 93, no. 11, pp. 5177$5184,1996$.

[146] E. Balada, M. Vilardell-Tarrés, and J. Ordi-Ros, "Implication of human endogenous retroviruses in the development of autoimmune diseases," International Reviews of Immunology, vol. 29, no. 4, pp. 351-370, 2010.

[147] M. S. Oberste, E. Gotuzzo, P. Blair et al., "Human febrile illness caused by encephalomyocarditis virus infection, peru," Emerging Infectious Diseases, vol. 15, no. 4, pp. 640-646, 2009.

[148] S. Nagafuchi, M. Teshima, Y. Kai et al., "The significance of tyrosine kinase 2 gene in encephalomyocarditis-D virusinduced diabetes as studied in Tyk2 gene knockout mice (P6334)," Journal of Immunology, vol. 190, pp. 182-119, 2013, (Meeting Abstract Supplement).

[149] B. Niklasson, K. E. Heller, B. Schønecker et al., "Development of type 1 diabetes in wild bank voles associated with islet autoantibodies the novel Ljungan virus," Experimental Diabesity Research, vol. 4, no. 1, pp. 35-44, 2003.

[150] M. Roivainen, P. Ylipaasto, C. Savolainen, J. Galama, T. Hovi, and T. Otonkoski, "Functional impairment and killing of human beta cells by enteroviruses: the capacity is shared by a wide range of serotypes, but the extent is a characteristic of individual virus strains," Diabetologia, vol. 45 , no. 5, pp. 693702, 2002.

[151] E. Cabrera-Rode, L. Sarmiento, C. Tiberti et al., "Type 1 diabetes islet associated antibodies in subjects infected by echovirus 16," Diabetologia, vol. 46, no. 10, pp. 1348-1353, 2003.

[152] E. Cabrera-Rode, L. Sarmiento, G. Molina et al., "Islet cell related antibodies and type 1 diabetes associated with echovirus 30 epidemic: a case report," Journal of Medical Virology, vol. 76, no. 3, pp. 373-377, 2005.

[153] O. Diaz-Horta, L. Sarmiento, A. Baj, E. Cabrera-Rode, and A. Toniolo, "Echovirus epidemics, autoimmunity, and type 1 diabetes," in Type 1 Diabetes - Pathogenesis, Genetics and Immunotherapy, D. Wagner, Ed., pp. 211-230, InTech, 2011, http://www.intechopen.com/books/type-1-diabetes-pathogenesis-genetics-and-immunotherapy/echovirus-epidemics-autoimmunity-and-type-1-diabetes.

[154] H. Hyoty and K. W. Taylor, "The role of viruses in human diabetes," Diabetologia, vol. 45, no. 10, pp. 1353-1361, 2002.

[155] T. Otonkoski, M. Roivainen, O. Vaarala et al., "Neonatal Type I diabetes associated with maternal echovirus 6 infection: a case report," Diabetologia, vol. 43, no. 10, pp. 1235-1238, 2000.

[156] Ç. H. Williams, S. Oikarinen, S. Tauriainen, K. Salminen, H. Hyöty, and G. Stanway, "Molecular analysis of an echovirus 3 
strain isolated from an individual concurrently with appearance of islet cell and IA-2 autoantibodies," Journal of Clinical Microbiology, vol. 44, no. 2, pp. 441-448, 2006.

[157] M. L. Sussman, L. Strauss, and H. L. Hodes, "Fatal coxsackie group B virus infection in the newborn; report of a case with necropsy findings and brief review of the literature," American Journal of Diseases of Children, vol. 97, no. 4, pp. 483-492, 1959.

[158] D. R. Gamble, M. L. Kinsley, M. G. FitzGerald, R. Bolton, and K. W. Taylor, "Viral antibodies in diabetes mellitus," British Medical Journal, vol. 3, no. 671, pp. 627-630, 1969.

[159] L. Andreoletti, D. Hober, C. Hober-Vandenberghe et al., "Detection of coxsackie B virus RNA sequences in whole blood samples from adult patients at the onset of type I diabetes mellitus," Journal of Medical Virology, vol. 52, no. 2, pp. 121-127, 1997.

[160] K. Sadeharju, A.-M. Hämäläinen, M. Knip et al., "Enterovirus infections as a risk factor for type I diabetes: virus analyses in a dietary intervention trial," Clinical and Experimental Immunology, vol. 132, no. 2, pp. 271-277, 2003.

[161] S. Tauriainen, S. Oikarinen, M. Oikarinen, and H. Hyöty, "Enteroviruses in the pathogenesis of type 1 diabetes," Seminars in Immunopathology, vol. 33, no. 1, pp. 45-55, 2011.

[162] L. Sarmiento, E. Cabrera-Rode, L. Lekuleni et al., "Occurrence of enterovirus RNA in serum of children with newly diagnosed type 1 diabetes and islet cell autoantibody-positive subjects in a population with a low incidence of type 1 diabetes," Autoimmunity, vol. 40, no. 7, pp. 540-545, 2007.

[163] M. Karvonen, M. Viik-Kajander, E. Moltchanova, I. Libman, R. LaPorte, and J. Tuomilehto, "Incidence of childhood type 1 diabetes worldwide," Diabetes Care, vol. 23, no. 10, pp. 1516-1526, 2000.

[164] J. W. Yoon, M. Austin, T. Onodera, and A. L. Notkins, "Virusinduced diabetes mellitus. Isolation of a virus from the pancreas of a child with diabetic ketoacidosis," The New England Journal of Medicine, vol. 300, no. 21, pp. 1173-1179, 1979.

[165] K. M. Drescher, K. Kono, S. Bopegamage, S. D. Carson, and S. Tracy, "Coxsackievirus B3 infection and type 1 diabetes development in NOD mice: Insulitis determines susceptibility of pancreatic islets to virus infection," Virology, vol. 329, no. 2, pp. 381-394, 2004.

[166] T. Kanno, K. Kim, K. Kono, K. M. Drescher, N. M. Chapman, and S. Tracy, "Group B coxsackievirus diabetogenic phenotype correlates with viral replication efficiency," Journal of Virology, vol. 80, no. 11, pp. 5637-5643, 2006.

[167] S. Tracy, K. M. Drescher, N. M. Chapman et al., "Toward testing the hypothesis that group B coxsackieviruses (CVB) trigger insulin-dependent diabetes: inoculating nonobese diabetic mice with CVB markedly lowers diabetes incidence," Journal of Virology, vol. 76, no. 23, pp. 12097-12111, 2002.

[168] S. Oikarinen, S. Tauriainen, D. Hober et al., "Virus antibody survey in different european populations indicates risk association between coxsackievirus B1 and type 1 diabetes," Diabetes, vol. 63, no. 2, pp. 655-662, 2014.

[169] O. H. Laitinen, H. Honkanen, O. Pakkanen et al., "Coxsackievirus $\mathrm{B} 1$ is associated with induction of $\beta$-cells autoimmunity that portends type 1 diabetes," Diabetes, vol. 63, no. 2, pp. 446455, 2014.

[170] S. Bopegamage, J. Precechtelova, L. Marosova et al., "Outcome of challenge with coxsackievirus B4 in young mice after maternal infection with the same virus during gestation," FEMS Immunology \& Medical Microbiology, vol. 64, no. 2, pp. 184-190, 2012.
[171] P. G. Larsson, T. Lakshmikanth, E. Svedin, C. King, and M. Flodström-Tullberg, "Previous maternal infection protects offspring from enterovirus infection and prevents experimental diabetes development in mice," Diabetologia, vol. 56, no. 4, pp. 867-874, 2013.

[172] G. Frisk and H. Diderholm, "Tissue culture of isolated human pancreatic islets infected with different strains of Coxsackievirus B4: assessment of virus replication and effects on islet morphology and insulin release," Experimental Diabesity Research, vol. 1, no. 3, pp. 165-175, 2000.

[173] M. Roivainen, S. Rasilainen, P. Ylipaasto et al., "Mechanisms of coxsackievirus-induced damage to human pancreatic $\beta$-cells," The Journal of Clinical Endocrinology and Metabolism, vol. 85, no. 1, pp. 432-440, 2000.

[174] S. A. Bopegamage and A. Petrovicova, "In vitro infection of mouse pancreatic islet cells with coxsackie viruses," Acta Virologica, vol. 38, no. 5, pp. 251-255, 1994.

[175] H. Yin, A.-K. Berg, J. Westman, C. Hellerström, and G. Frisk, "Complete nucleotide sequence of a coxsackievirus B-4 strain capable of establishing persistent infection in human pancreatic islet cells: effects on insulin release, proinsulin synthesis, and cell morphology," Journal of Medical Virology, vol. 68, no. 4, pp. 544-557, 2002.

[176] M. Roivainen, P. Ylipaasto, J. Ustinov, T. Hovi, and T. Otonkoshi, "Screening enteroviruses for $\beta$-cell tropism using foetal porcine $\beta$-cells," Journal of General Virology, vol. 82, no. 8, pp. 1909-1916, 2001.

[177] T. M. Szopa, D. R. Gamble, and K. W. Taylor, "Biochemical changes induced by Coxsackie B4 virus in short-term culture of mouse pancreatic islets," Bioscience Reports, vol. 5, no. 1, pp. 63-69, 1985.

[178] N. Welsh, B. Margulis, L. A. Borg et al., "Differences in the expression of heat-shock proteins and antioxidant enzymes between human and rodent pancreatic islets: implications for the pathogenesis of insulin-dependent diabetes mellitus," Molecular Medicine, vol. 1, no. 7, pp. 806-820, 1995.

[179] G. G. Dahlquist, J. E. Boman, and P. Juto, "Enteroviral RNA and IgM antibodies in early pregnancy and risk for childhood-onset IDDM in offspring," Diabetes Care, vol. 22, no. 2, pp. 364-365, 1999.

[180] M. Elfving, J. Svensson, S. Oikarinen et al., "Maternal enterovirus infection during pregnancy as a risk factor in offspring diagnosed with type 1 diabetes between 15 and 30 years of age," Experimental diabetes research, vol. 2008, pp. 271958271964, 2008.

[181] H. Viskari, J. Ludvigsson, R. Uibo et al., "Relationship between the incidence of type 1 diabetes and maternal enterovirus antibodies: time trends and geographical variation," Diabetologia, vol. 48, no. 7, pp. 1280-1287, 2005.

[182] H. R. Viskari, M. Roivainen, A. Reunanen et al., "Maternal firsttrimester enterovirus infection and future risk of type 1 diabetes in the exposed fetus," Diabetes, vol. 51, no. 8, pp. 2568-2571, 2002.

[183] R. Coutant, J. C. Carel, P. Lebon, L. Cantero-Aguilar, P. Lebon, and P. F. Bougnères, "Detection of enterovirus RNA sequences in serum samples from autoantibody-positive subjects at risk for diabetes," Diabetic Medicine, vol. 19, no. 11, pp. 968-969, 2002.

[184] G. Frisk and H. Diderholm, "Antibody responses to different strains of Coxsackie B4 virus in patients with newly diagnosed type I diabetes mellitus or aseptic meningitis," Journal of Infection, vol. 34, no. 3, pp. 205-210, 1997. 
[185] G. Frisk and T. Tuvemo, "Enterovirus infections with $\beta$-cell tropic strains are frequent in siblings of children diagnosed with type 1 diabetes children and in association with elevated levels of GAD65 antibodies," Journal of Medical Virology, vol. 73, no. 3, pp. 450-459, 2004.

[186] M. M. Maha, M. A. Ali, S. E. Abdel-Rehim, E. A. Abu-Shady, B. M. El-Naggar, and Y. Z. Maha, "The role of coxsackieviruses infection in the children of insulin dependent diabetes mellitus.", The Journal of the Egyptian Public Health Association, vol. 78, no. 3-4, pp. 305-318, 2003.

[187] R. Varela-Calvino, R. Ellis, G. Sgarbi, C. M. Dayan, and M. Peakman, "Characterization of the T-cell response to coxsackievirus B4: evidence that effector memory cells predominate in patients with type 1 diabetes," Diabetes, vol. 51, no. 6, pp. 1745-1753, 2002.

[188] L. C. Stene, S. Oikarinen, H. Hyöty et al., "Enterovirus infection and progression from islet autoimmunity to type 1 diabetes: the Diabetes and Autoimmunity Study in the Young (DAISY)," Diabetes, vol. 59, no. 12, pp. 3174-3180, 2010.

[189] S. Oikarinen, M. Martiskainen, S. Tauriainen et al., "Enterovirus RNA in blood is linked to the development of type 1 diabetes," Diabetes, vol. 60, no. 1, pp. 276-279, 2011.

[190] K. K. Salminen, T. Vuorinen, S. Oikarinen et al., "Isolation of enterovirus strains from children with preclinical Type 1 diabetes," Diabetic Medicine, vol. 21, no. 2, pp. 156-164, 2004.

[191] G. G. Dahlquist, J. Forsberg, L. Hagenfeldt, J. Boman, and P. Juto, "Increased prevalence of enteroviral RNA in blood spots from newborn children who later developed type 1 diabetes: a population-based case-control study," Diabetes Care, vol. 27, no. 1, pp. 285-286, 2004.

[192] G. B. Clements, D. N. Galbraith, and K. W. Taylor, "Coxsackie B virus infection and onset of childhood diabetes," The Lancet, vol. 346, no. 8969, pp. 221-223, 1995.

[193] M. E. Craig, N. J. Howard, M. Silink, and W. D. Rawlinson, "Reduced frequency of HLA DRB1-03, DQB1-02 in children with type 1 diabetes associated with enterovirus RNA," Journal of Infectious Diseases, vol. 187, no. 10, pp. 1562-1570, 2003.

[194] H. Kawashima, T. Ihara, H. Ioi et al., "Enterovirus-related type 1 diabetes mellitus and antibodies to glutamic acid decarboxylase in Japan," Journal of Infection, vol. 49, no. 2, pp. 147-151, 2004.

[195] C. Nairn, D. N. Galbraith, K. W. Taylor, and G. B. Clements, "Enterovirus variants in the serum of children at the onset oftype 1 diabetes mellitus," Diabetic Medicine, vol. 16, no. 6, pp. 509-513, 1999.

[196] H. Yin, A.-K. Berg, T. Tuvemo, and G. Frisk, "Enterovirus RNA is found in peripheral blood mononuclear cells in a majority of type 1 diabetic children at onset," Diabetes, vol. 51, no. 6, pp. 1964-1971, 2002.

[197] A. Toniolo, G. Maccari, G. Federico et al., "Are enterovirus infections linked to the early stages of type 1 diabetes?" in Proceedings of the American Society for Microbiology Meeting, CA. Abst. ST-902, San Diego, Calif, USA, 2010.

[198] B. M. Schulte, J. Bakkers, K. H. W. Lanke et al., "Detection of enterovirus RNA in peripheral blood mononuclear cells of type 1 diabetic patients beyond the stage of acute infection," Viral Immunology, vol. 23, no. 1, pp. 99-104, 2010.

[199] H. Champsaur, E. Dussaix, D. Samolyk, M. Fabre, C. Bach, and R. Assan, "Diabetes and Coxsackie virus B5 infection," The Lancet, vol. 315, no. 8162, p. 251, 1980.

[200] C. di Pietro, M. J. del Guercio, G. P. Paolino, M. Barbi, P. Ferrante, and G. Chiumello, "Type 1 diabetes and Coxsackie virus infection," Helvetica Paediatrica Acta, vol. 34, no. 6, pp. 557-561, 1979.
[201] P. Ylipaasto, K. Klingel, A. M. Lindberg et al., "Enterovirus infection in human pancreatic islet cells, islet tropism in vivo and receptor involvement in cultured islet beta cells," Diabetologia, vol. 47, no. 2, pp. 225-239, 2004.

[202] F. Dotta, S. Censini, A. G. S. van Halteren et al., "Coxsackie B4 virus infection of $\beta$ cells and natural killer cell insulitis in recent-onset type 1 diabetic patients," Proceedings of the National Academy of Sciences of the United States of America, vol. 104, no. 12, pp. 5115-5120, 2007.

[203] M. Oikarinen, S. Tauriainen, T. Honkanen et al., "Analysis of pancreas tissue in a child positive for islet cell antibodies," Diabetologia, vol. 51, no. 10, pp. 1796-1802, 2008.

[204] S. J. Richardson, A. Willcox, A. J. Bone, A. K. Foulis, and N. G. Morgan, "The prevalence of enteroviral capsid protein vp1 immunostaining in pancreatic islets in human type 1 diabetes," Diabetologia, vol. 52, no. 6, pp. 1143-1151, 2009.

[205] P. Ylipaasto, B. Kutlu, S. Rasilainen et al., "Global profiling of coxsackievirus- and cytokine-induced gene expression in human pancreatic islets," Diabetologia, vol. 48, no. 8, pp. 1510 1522, 2005.

[206] D. P. Strachan, "Hay fever, hygiene, and household size," British Medical Journal, vol. 299, no. 6710, pp. 1259-1260, 1989.

[207] J. F. Bach, "The effect of infections on susceptibility to autoimmune and allergic diseases," The New England Journal of Medicine, vol. 347, no. 12, pp. 911-920, 2002.

[208] H. S. Lee, T. Briese, C. Winkler et al., "Next-generation sequencing for viruses in children with rapid-onset type 1 diabetes," Diabetologia, vol. 56, no. 8, pp. 1705-1711, 2013.

[209] T. Boettler and M. Von Herrath, "Protection against or triggering of Type 1 diabetes? Different roles for viral infections," Expert Review of Clinical Immunology, vol. 7, no. 1, pp. 45-53, 2011.

[210] N. M. Chapman, K. Coppieters, M. von Herrath, and S. Tracy, "The microbiology of human hygiene and its impact on type 1 diabetes," Islets, vol. 4, no. 4, pp. 253-261, 2012.

[211] K. M. Drescher and S. Tracy, "The CVB and etiology of type 1 diabetes," Current Topics in Microbiology and Immunology, vol. 323, pp. 259-274, 2008.

[212] H. Al-Hello, B. Davydova, T. Smura et al., "Phenotypic and genetic changes in coxsackievirus B5 following repeated passage in mouse pancreas in vivo," Journal of Medical Virology, vol. 75, no. 4, pp. 566-574, 2005.

[213] M. Flodström, A. Maday, D. Balakrishna, M. M. Cleary, A. Yoshimura, and N. Sarvetnick, "Target cell defense prevents the development of diabetes after viral infection," Nature Immunology, vol. 3, no. 4, pp. 373-382, 2002.

[214] G. Frisk, K. Jansson, M. Ericsson, and H. Diderholm, "Differences in inhibition of replication between Coxsackie B4 virus strains in various cell lines by antibodies to some cell surface proteins," Virus Research, vol. 73, no. 2, pp. 121-130, 2001.

[215] T. M. Szopa, P. A. Titchener, N. D. Portwood, and K. W. Taylor, "Diabetes mellitus due to viruse-some recent developments," Diabetologia, vol. 36, no. 8, pp. 687-695, 1993.

[216] E. Jaeckel, M. Manns, and M. von Herrath, "Viruses and diabetes," Annals of the New York Academy of Sciences, vol. 958, pp. 7-25, 2002.

[217] S. Skarsvik, J. Puranen, J. Honkanen et al., "Decreased in vitro type 1 immune response against coxsackie virus B4 in children with type 1 diabetes," Diabetes, vol. 55, no. 4, pp. 996-1003, 2006.

[218] K. Klingel, S. Stephan, M. Sauter et al., "Pathogenesis of murine enterovirus myocarditis: virus dissemination and immune cell targets," Journal of Virology, vol. 70, no. 12, pp. 8888-8895, 1996. 
[219] B. O. Roep, H. S. Hiemstra, N. C. Schloot et al., "Molecular mimicry in type 1 diabetes: immune cross-reactivity between islet autoantigen and human cytomegalovirus but not Coxsackie virus," Annals of the New York Academy of Sciences, vol. 958, pp. 163-165, 2002.

[220] M. A. Atkinson, M. A. Bowman, L. Campbell, B. L. Darrow, D. L. Kaufman, and N. K. Maclaren, "Cellular immunity to a determinant common to glutamate decarboxylase and Coxsackie virus in insulin-dependent diabetes," The Journal of Clinical Investigation, vol. 94, no. 5, pp. 2125-2129, 1994.

[221] W. Richter, T. Mertens, B. Schoel et al., "Sequence homology of the diabetes-associated autoantigen glutamate decarboxylase with coxsackie B4-2C protein and heat shock protein 60 mediates no molecular mimicry of autoantibodies," Journal of Experimental Medicine, vol. 180, no. 2, pp. 721-726, 1994.

[222] N. C. Schloot, S. J. M. Willemen, G. Duinkerken, J. W. Drijfhout, R. R. P. de Vries, and B. O. Roep, "Molecular mimicry in type 1 diabetes mellitus revisited: T-cell clones to GAD65 peptides with sequence homology to coxsackie or proinsulin peptides do not crossreact with homologous counterpart," Human Immunology, vol. 62, no. 4, pp. 299-309, 2001.

[223] R. S. Fujinami, M. G. von Herrath, U. Christen, and J. L. Whitton, "Molecular mimicry, bystander activation, or viral persistence: infections and autoimmune disease," Clinical Microbiology Reviews, vol. 19, no. 1, pp. 80-94, 2006.

[224] M. S. Horwitz, A. Ilic, C. Fine, E. Rodriguez, and N. Sarvetnick, "Presented antigen from damaged pancreatic $\beta$ cells activates autoreactive $\mathrm{T}$ cells in virus-mediated autoimmune diabetes," Journal of Clinical Investigation, vol. 109, no. 1, pp. 79-87, 2002.

[225] G. R. Vreugdenhil, P. G. Wijnands, M. G. Netea, J. W. M. van der Meer, W. J. G. Melchers, and J. M. D. Galama, "Enterovirus-induced production of pro-inflammatory and Thelper cytokines by human leukocytes," Cytokine, vol. 12, no. 12, pp. 1793-1796, 2000.

[226] G. R. Vreugdenhil, P. G. Wijnands, M. G. Netea et al., "Coxsackie $\mathrm{B}$ virus induces TNF- $\alpha$ production in human pancreatic ductal cells," in Enterovirus and Type 1 Diabetes Mellitus: Putative Pathogenic Pathways, G. R. Vreugdenhil, Ed., dissertation thesis, Print Panters Iskamp, Enschede, The Netherlands, 2001.

[227] M. S. Horwitz, A. Ilic, C. Fine, B. Balasa, and N. Sarvetnick, "Coxsackieviral-mediated diabetes: induction requires antigenpresenting cells and is accompanied by phagocytosis of beta cells," Clinical Immunology, vol. 110, no. 2, pp. 134-144, 2004.

[228] M. S. Horwitz, C. Fine, A. Ilic, and N. Sarvetnick, "Requirements for viral-mediated autoimmune diabetes: $\beta$-cell damage and immune infiltration," Journal of Autoimmunity, vol. 16, no. 3, pp. 211-217, 2001.

[229] D. Hober, W. Chehadeh, J. Weill et al., "Circulating and cellbound antibodies increase coxsackievirus B4-induced production of IFN- $\alpha$ by peripheral blood mononuclear cells from patients with type 1 diabetes," Journal of General Virology, vol. 83, no. 9, pp. 2169-2176, 2002.

[230] W. Chehadeh, A. Bouzidi, G. Alm, P. Wattré, and D. Hober, "Human antibodies isolated from plasma by affinity chromatography increase the coxsackievirus B4-induced synthesis of interferon- $\alpha$ by human peripheral blood mononuclear cells in vitro," Journal of General Virology, vol. 82, no. 8, pp. 18991907, 2001.

[231] D. Hober, W. Chehadeh, A. Bouzidi, and P. Wattré, "Antibodydependent enhancement of Coxsackievirus B4 infectivity of human peripheral blood mononuclear cells results in increased interferon- $\alpha$ synthesis," Journal of Infectious Diseases, vol. 184, no. 9, pp. 1098-1108, 2001.

[232] P. Sauter, P.-E. Lobert, B. Lucas et al., "Role of the capsid protein VP4 in the plasma-dependent enhancement of the Coxsackievirus B4E2-infection of human peripheral blood cells," Virus Research, vol. 125, no. 2, pp. 183-190, 2007.

[233] P. Sauter, W. Chehadeh, P.-E. Lobert et al., "A part of the VP4 capsid protein exhibited by coxsackievirus B4 E2 is the target of antibodies contained in plasma from patients with type 1 diabetes," Journal of Medical Virology, vol. 80, no. 5, pp. 866878, 2008.

[234] J. G. Rosmalen, W. van Ewijk, and P. J. Leenen, "T-cell education in autoimmune diabetes: teachers and students," Trends in Immunology, vol. 23, no. 1, pp. 40-46, 2002.

[235] F. Brilot, H. Jaidane, V. Geenen, and D. Hober, "Coxsackievirus B4 infection of murine foetal thymus organ cultures," Journal of Medical Virology, vol. 80, no. 4, pp. 659-666, 2008.

[236] H. Jaïdane, J. Gharbi, P.-E. Lobert et al., "Prolonged viral RNA detection in blood and lymphoid tissues from Coxsackievirus B4 E2 orally-inoculated Swiss mice," Microbiology and Immunology, vol. 50, no. 12, pp. 971-974, 2006.

[237] H. Jaïdane, P. Sauter, F. Sane, A. Goffard, J. Gharbi, and D. Hober, "Enteroviruses and type 1 diabetes: towards a better understanding of the relationship," Reviews in Medical Virology, vol. 20, no. 5, pp. 265-280, 2010.

[238] O. Vaarala, "Leaking gut in type 1 diabetes," Current Opinion in Gastroenterolgy, vol. 24, no. 6, pp. 701-706, 2008.

[239] X. Xu, J. D’Hoker, G. Stangé et al., “ $\beta$ cells can be generated from endogenous progenitors in injured adult mouse pancreas," Cell, vol. 132, no. 2, pp. 197-207, 2008.

[240] S. Bonner-Weir, " $\beta$-cell turnover: its assessment and implications," Diabetes, vol. 50, no. 1, pp. S20-S24, 2001.

[241] M. Almgren, T. Schlinzig, D. Gomez-Cabrero et al., "Cesarean delivery and hematopoietic stem cell epigenetics in the newborn infant: implications for future health?" The American Journal of Obstetric and Gynecology, vol. 211, no. 5, pp. 502.e1502.e8, 2014. 


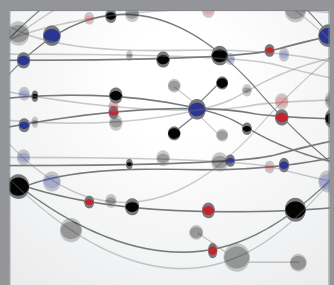

The Scientific World Journal
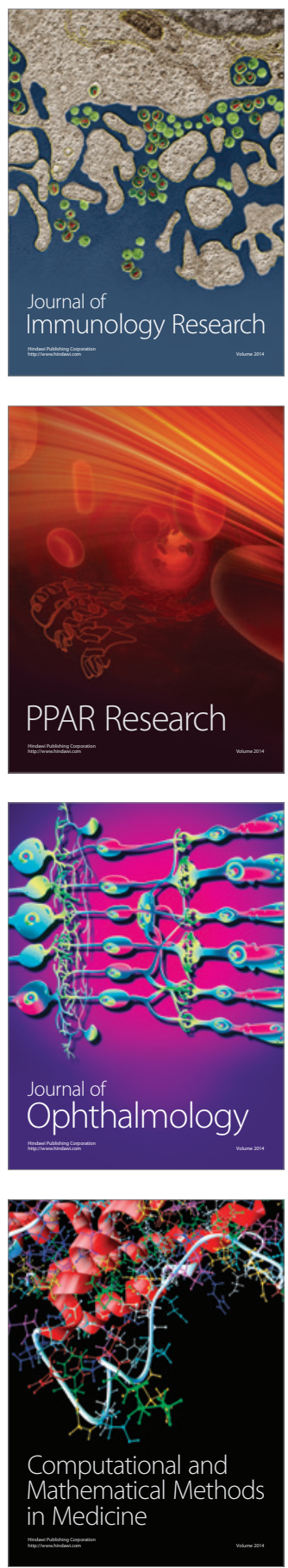

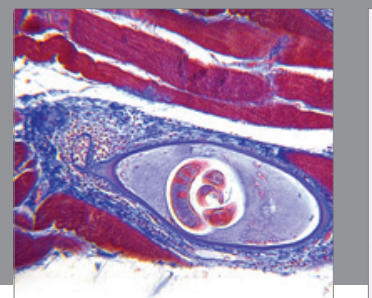

Gastroenterology

Research and Practice
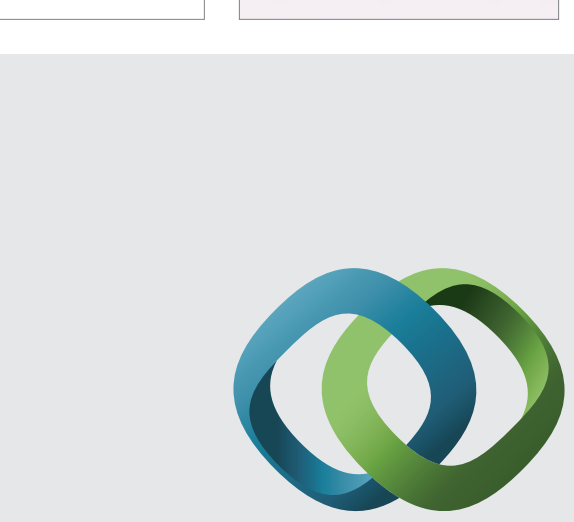

\section{Hindawi}

Submit your manuscripts at

http://www.hindawi.com
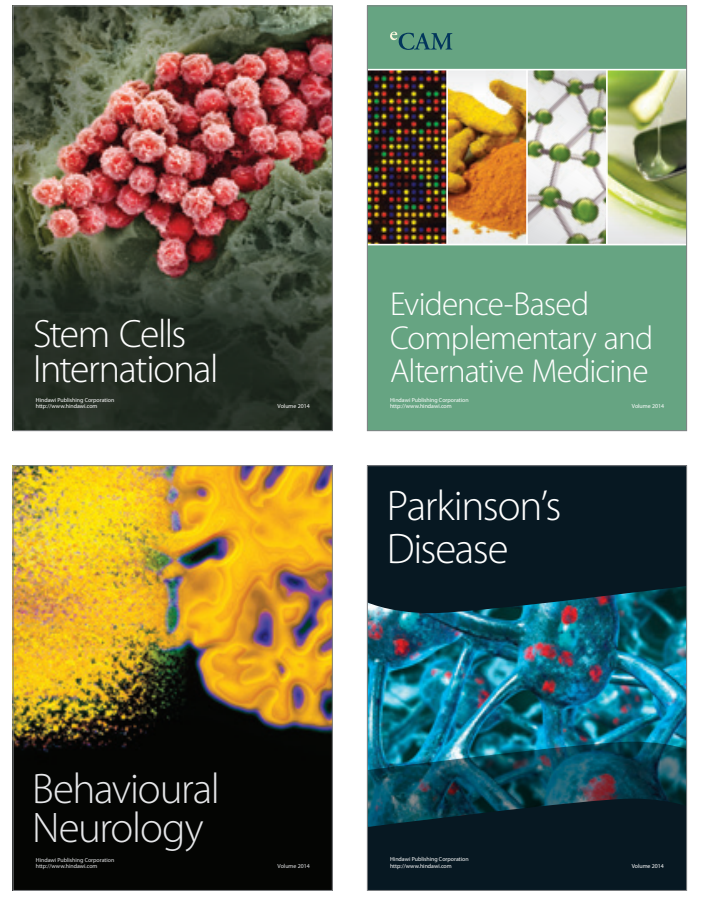
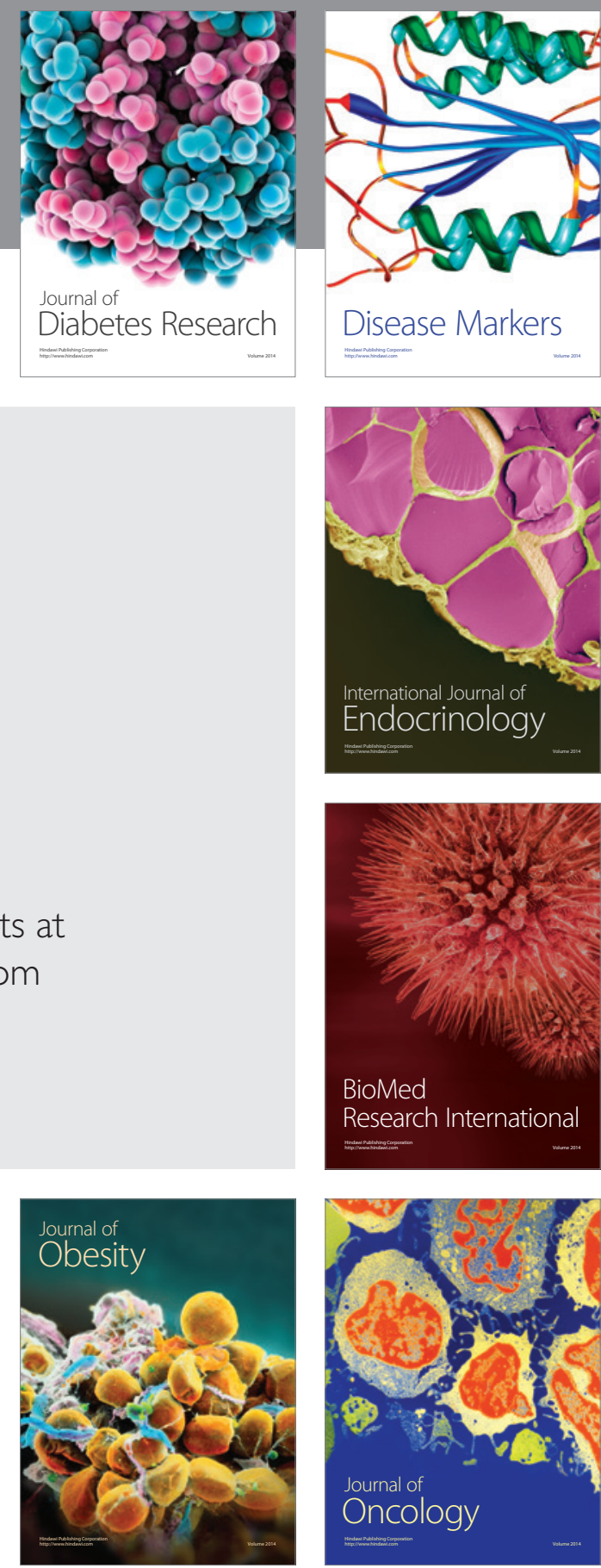

Disease Markers
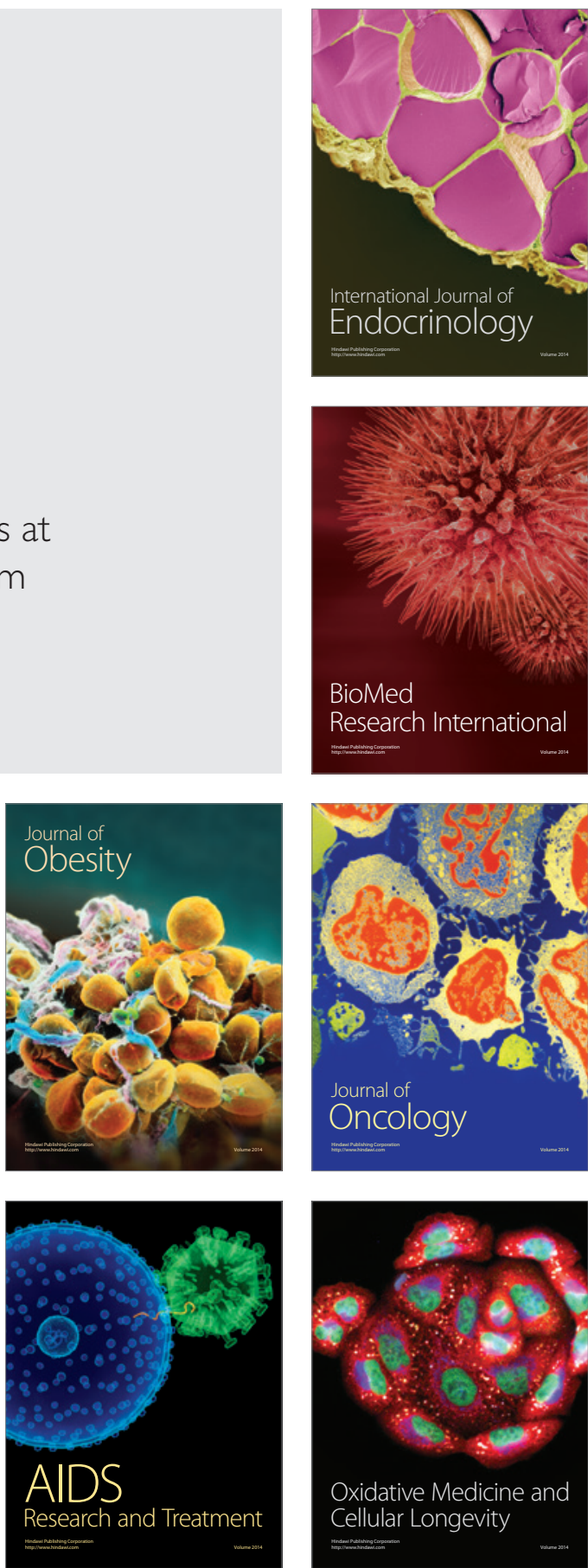